\title{
Sewage Treatment through Constructed Wetland System Tailed by Nanocomposite Clay Filter: A Clean Green Initiative
}

\author{
Boopathy Usharani ${ }^{1, a}$ and Namasivayam Vasudevan ${ }^{2, b}$ \\ 1Department of Biochemistry, VISTAS, Chennai 600117 \\ ${ }^{2}$ Centre for Environmental Studies, Anna University, Chennai 600025 \\ araniushab1@gmail.com, bprofnvasu30@gmail.com
}

\begin{abstract}
Keywords: Nanocomposite clay filter; disinfection; constructed wetland system; Cyperus alternifolius
\end{abstract}

\begin{abstract}
Sewage treatment through constructed wetland is an ecofriendly and sustainable approach proven effective worldwide. Constructed wetland with appropriate species is capable of eliminating all pollutants in sewage, except pathogen removal. An additional polishing treatment is required to eliminate pathogen. Optimization of HLR in CWS was executed by applying first order kinetics. Nanocomposite clay filter with economically viable materials was synthesized and disinfection ability was evaluated. A novel approach integrating constructed wetland system tailed by nanocomposite clay filter was designed. Control was setup with constructed wetland system devoid of plants integrated with clay filter devoid of nanoparticles. The constructed wetland system devoid of plants was used as plants play a vital role in the removal of pollutants. The quality of the influent for $(\mathrm{n}=20) \mathrm{BOD}, \mathrm{COD}, \mathrm{TKN}, \mathrm{TP}, \mathrm{TSS}, \mathrm{TDS}, \mathrm{SO}_{4}, \mathrm{Cl}$, lead and iron were 248, 345, 26, 4.8, 350, 450, $50,48,0.2,5 \mathrm{mg} / \mathrm{L}$ respectively. The quality of effluent in the control was $145,225,18,3.8,185$, $345,31,30,0.6,2 \mathrm{mg} / \mathrm{L}$ for BOD,COD, TKN, TP, TSS, TDS, $\mathrm{SO}_{4}, \mathrm{Cl}$, lead and iron respectively. While in the test, 10, 30, 2, 1, 30, 128, 13, 12, BDL, BDL mg/L for BOD, COD, TKN, TP,TSS, TDS, $\mathrm{SO}_{4}, \mathrm{Cl}$, lead and iron respectively. The inlet concentration of T.C, F.C and E.coli were $42.1 \times 10^{6}-$ $6.3 \times 10^{8}, 4.9 \times 10^{5}-14.4 \times 10^{6}$ and $7.8 \times 10^{3}-3.8 \times 10^{5}$ respectively. The pathogen reduction in log removal for test and control units were 5.4 and 1.1 for T.C, 4.4 and 1.2 for F.C and 3 and 1 for E.coli. Thus it is a clean green initiative combating the limitations of disinfection surpassing the existing barriers.
\end{abstract}

\section{Introduction}

Wastewater is generally classified into three different types: domestic, industrial and storm water. Recent findings implicate that about $80 \%$ of the wastewater generated worldwide is being discharged into water bodies without treatment (WWAP 2017) thus, polluting the environment and disturbing ecological balance (Wakelin et al. 2008). Wastewater discharge from domestic, industrial and agricultural sector releases a wide range of contaminants drawing keen attention of all the researchers and environmentalists worldwide. Water bodies were once considered as natural resource but now treated as dumping ground. Different sources contribute to the contamination of water bodies. Some of them are direct sources such as letting of untreated sewage (Norah et al. 2015), effluent discharge from factories and refineries (Qazi \& Qazi 2008). The list of pollutants released in wastewater keeps increasing at an alarming rate day by day due to anthropogenic inputs. The various components of domestic wastewater are biodegradable, other organic materials, nutrients, heavy metals, microorganisms and inorganic materials.

Treated sewage discharged into the environment contribute to pathogens in the environment and needs appropriate treatment. The methods adopted for disinfection in wastewater treatment plants has its own limitations. UV treatment for disinfection is not cost effective and suspended solids in water may lead to inefficiency in disinfection treatment. It requires continuous supply of electricity and is effective only at proximal points and not at distal points. Ozonation requires increased capital cost and skilled labours. Unlike UV treatment, ozonation is also effective only at the point of use. It has short half- life and needs to be produced on-site (EPA 2015). Chlorination is effective on bacterial pathogens but its disadvantages includes; inability to penetrate through protozoans and biofilm, production of harmful byproducts that affects aquatic life (Ibrahim et.al.2015). 
Constructed wetlands are best suited for developing countries with tropical climate due to conducive higher biological activity and productivity than temperate climate (Varma et al 2020). More oxygenated environment exists in vertical flow constructed wetlands leading to significant removal of organic matter and microbes in wastewater. Performance of constructed wetlands with appropriate plant species could efficiently remove organics, nutrients, heavy metals (Sahu 2014) and total coliforms of $3.9 \mathrm{log}$ units (Zurita \& White 2014). Removal of coliforms in constructed wetland is less effective and thus requires a polishing treatment before its reuse in agriculture sector (Varma et al 2020). In the current scenario, nanotechnology is the best fit for effective removal of microbes since pathogens are resistant to the conventional disinfection techniques (Grasso et al 2019). Nanotechnology is the cutting edge technology in disinfection process. Thus an initiative integrating the conventional constructed wetland system with the selected species and modern nanotechnology was taken as a research plan integrating these two processes. Constructed wetland system tailed by disinfection unit encompassing nanocomposite particles was executed. The objective was framed to evaluate the disinfection efficiency of a constructed wetland system integrated with nanocomposite clay filter for sewage treatment

\section{Result and Discussion}

\subsection{Optimisation of HLR in CWS.}

Published literature on optimisation studies revealed that application of first order kinetics fitted well for removal efficiency of BOD, COD, TSS, TKN and TP. The theoretical HRT for the respective HLR with flow rate is presented in Table 2.1.

Table 2.1 HRT of respective HLR

\begin{tabular}{|c|c|c|}
\hline Flow rate & HLR & HRT (days) \\
\hline $0.02 \mathrm{~m}^{3} / \mathrm{d}$ & $28 \mathrm{~mm} / \mathrm{d}$ & 12 \\
\hline $0.04 \mathrm{~m}^{3} / \mathrm{d}$ & $56 \mathrm{~mm} / \mathrm{d}$ & 6.8 \\
\hline $0.06 \mathrm{~m}^{3} / \mathrm{d}$ & $84 \mathrm{~mm} / \mathrm{d}$ & 4.32 \\
\hline $0.08 \mathrm{~m}^{3} / \mathrm{d}$ & $112 \mathrm{~mm} / \mathrm{d}$ & 3.24 \\
\hline
\end{tabular}

Table 2.2 Rate constant values and mass removal rate at different HLRs

\begin{tabular}{|c|c|c|c|c|}
\hline Parameters & $\begin{array}{c}\text { HLR } \\
\mathrm{mm} / \mathrm{d}\end{array}$ & $\begin{array}{l}\text { Mass removal } \\
\text { rate }\left(\mathrm{g} \mathrm{m}^{-2} \mathrm{~d}^{-1}\right)\end{array}$ & $\begin{array}{c}\text { Areal removal rate } \\
\text { constant } \\
K_{A}\left(\mathbf{m ~ d}^{-1}\right)\end{array}$ & $\begin{array}{c}\text { Volumetric removal rate } \\
\text { constant } \\
K_{V}\left(\mathbf{d}^{-1}\right)\end{array}$ \\
\hline \multirow{4}{*}{ BOD } & 28 & 4.06 & 0.02 & \begin{tabular}{|c|}
0.07 \\
\end{tabular} \\
\hline & 56 & 9.07 & 0.06 & 0.17 \\
\hline & 84 & 18.06 & 0.18 & 0.52 \\
\hline & 112 & 20.38 & 0.15 & 0.43 \\
\hline \multirow{4}{*}{ COD } & 28 & 6.16 & 0.02 & 0.08 \\
\hline & 56 & 13.16 & 0.06 & 0.17 \\
\hline & 84 & 26.04 & 0.18 & 0.5 \\
\hline & 112 & 28.56 & 0.14 & 0.40 \\
\hline \multirow{4}{*}{ TSS } & 28 & 6.9 & 0.04 & 0.12 \\
\hline & 56 & 14.4 & 0.09 & 0.25 \\
\hline & 84 & 23.9 & 0.18 & 0.51 \\
\hline & 112 & 28.5 & 0.17 & 0.49 \\
\hline \multirow{4}{*}{ TKN } & 28 & 0.57 & 0.04 & 0.12 \\
\hline & 56 & 1.21 & 0.10 & 0.27 \\
\hline & 84 & 1.97 & 0.19 & 0.54 \\
\hline & 112 & 2.35 & 0.18 & 0.50 \\
\hline \multirow{4}{*}{$\mathrm{TP}$} & 28 & 0.07 & 0.02 & 0.08 \\
\hline & 56 & 0.18 & 0.07 & 0.20 \\
\hline & 84 & 0.30 & 0.13 & 0.37 \\
\hline & 112 & 0.33 & 0.12 & 0.33 \\
\hline
\end{tabular}


The mass removal rate, $\mathrm{k}$ values of areal removal rate constant and volumetric removal rate constant of the present study is presented in Table 3.2. In the present study, first order kinetics fitted well for removal of organics and nutrients till $84 \mathrm{~mm} / \mathrm{d}$. The removal efficiency at the highest HLR of $112 \mathrm{~mm} / \mathrm{d}$ is slightly less. It may be due to little over loading and spillage of influent. Similar condition was explained by Trang et al. (2010), at HLR $146 \mathrm{~mm} / \mathrm{d}$. In HFCWS, applying Kickuth equation of first order kinetics revealed that hydraulic and pollutant loading strongly influenced wetland performance in removal of organics. Monad model of first order kinetics predicted the removal of nitrogen in constructed wetland system (Gajewska \& Skrypiec 2018). Trang et al. (2010), conducted experiments under tropical climatic conditions at 4 HLRs: $31 \mathrm{~mm} / \mathrm{d}, 62 \mathrm{~mm} / \mathrm{d}, 104 \mathrm{~mm}$ $/ \mathrm{d}$ and $146 \mathrm{~mm} / \mathrm{d}$ and concluded that applying first order kinetics fitted well for all parameters up to $104 \mathrm{~mm} / \mathrm{d}$. The $\mathrm{K}_{v}$ and $\mathrm{K}_{A}$ values were similar for BOD, COD, TKN and TSS while, the values of TP was little lesser confirming the significant removal range of the pollutants.

\subsection{Optimisation of disinfection studies in clay disc}

Optimisation studies were carried out in both batch and continuous mode to evaluate the required contact time for disinfection of E.coli. Batch studies revealed zero cell count in 20 minutes at all flow rates for 5 discs. However, as the number of discs increased, zero cell count was achieved earlier at all flow rates. E.coli cell count was inversely proportional to the number of discs in contact for batch and continuous mode. In continuous mode, complete disinfection was attained in 10 minutes at all flow rates in column loaded with 10 and 15 discs. While, in column loaded with 5 discs reduced colony count was observed in 10 minutes and complete disinfection was achieved in 20 minutes.

\subsection{Integration of CWS tailed by nanocomposite clay filter}

The results of removal efficiency of organics, nutrients, heavy metals and pathogen in test and control units were dealt in the following and discussed with similar works in published literature.

\subsubsection{Efficiency of Organics Removal}

The concentration of BOD in the inlet ranged from $228-252 \mathrm{mg} / \mathrm{L}$. Results revealed that the removal efficiency of BOD were $93 \pm 4 \%$ for test and $33 \pm 6 \%$ for control. The results of BOD removal in the control and experimental set up are presented in Fig. 2.1. The concentration of BOD in the effluent was 145 and $10 \mathrm{mg} / \mathrm{L}$ in control and test respectively. Higher removal efficiency of BOD in planted beds is attributed by oxygenation of bed by plant roots favoring aerobic degradation. One of the major mechanism involved in organic removal is oxygenation through plant roots. Hence, it is obvious that efficiency of planted ones will be superior to unplanted ones.

Klomjek (2016) reported $94 \%$ and $77 \%$ of BOD removal in test and control when giant Napier grass was used in treatment of domestic wastewater in VFCWS at HLR of $5 \mathrm{~cm} / \mathrm{d}$. The unplanted had BOD removal efficiency of 31.6-54\% while Cyperus papyrus based CWS $68.6-86.5 \%$ and Miscanthidium violaceum 46.7-61.1\% (Kyambadde et al. 2005). Studies conducted by Arivoli \& Mohanraj (2013) revealed removal of $75.49 \%$ and $80.53 \%$ of BOD and COD in CWS planted with Typha angustifolia while, $64.5 \%$ and $56.45 \%$ removal of BOD and COD in unplanted. More than $75 \%$ removal of BOD was achieved with Typha plantation and $63 \%$ without plantation (Karathanasis et al. 2003). Albalawneh et al. (2016) reported a removal efficiency of 50\% and $37 \%$ of BOD was achieved in control beds with fine media and coarse media. While, in beds planted with reeds $67 \%$ and $62 \%$ was attained in fine and coarse media. It was inferred that $\%$ removal in control units differ depending on the media. 


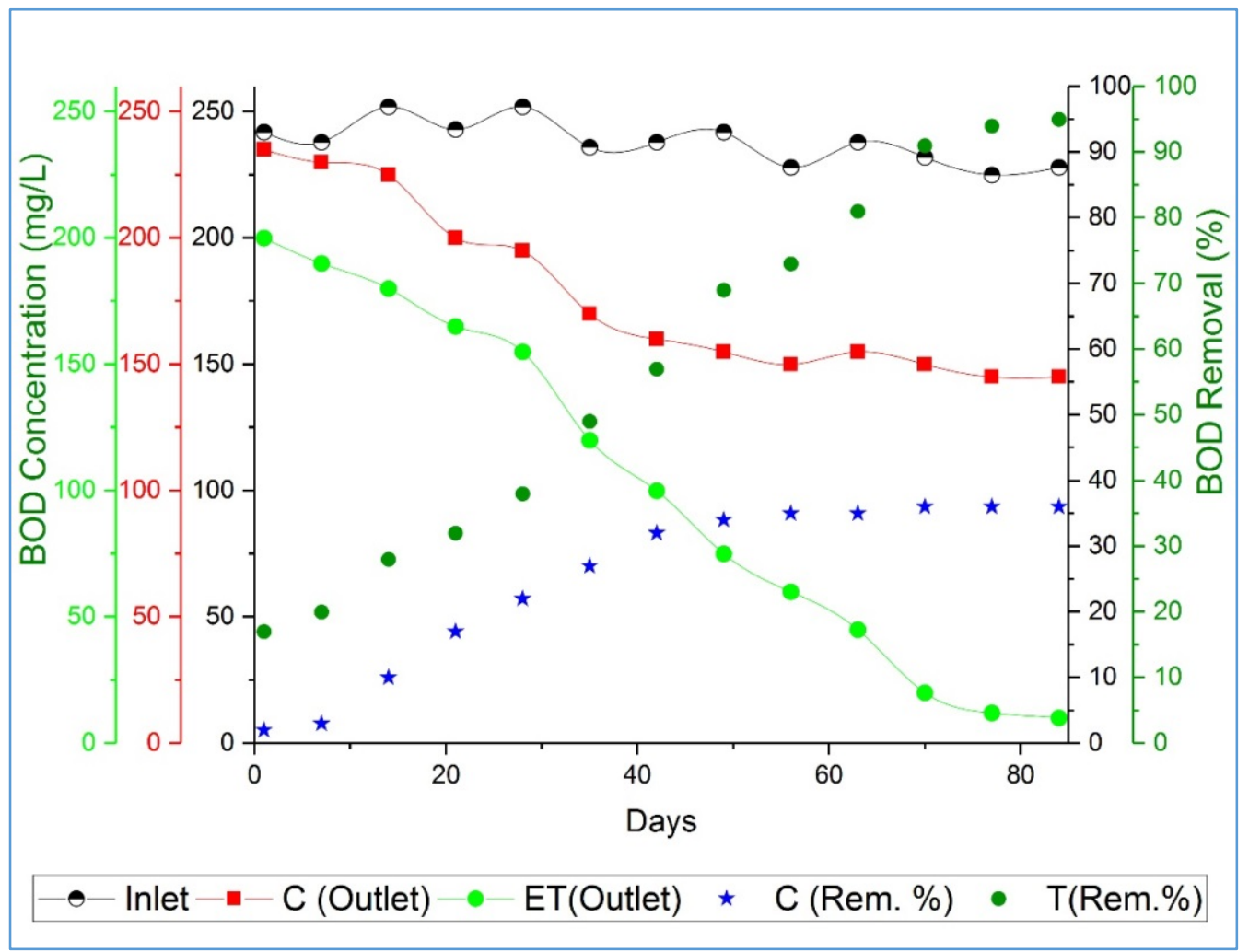

Figure 2.1 Efficiency of BOD removal

The concentration of COD in the inlet ranged from 302-346 mg/L. Results revealed that the removal efficiency of COD were $91 \pm 3 \%$ for test and $24 \pm 8 \%$ for control. The results of COD removal in the control and experimental set up are presented in Fig. 2.2. The concentration of COD in the effluent was 225 and $30 \mathrm{mg} / \mathrm{L}$ in control and test respectively. Collison \& Grismer (2013) reported a total organic removal of $78.8 \%$ and $76.1 \%$ in planted and unplanted CWS with removal of COD up to $79 \%$ and $76 \%$ in planted and unplanted CWS. The average removal efficiency of $88 \%$ COD and 91\% BOD in planted and $83 \%$ and $87 \%$ for unplanted was reported by Abou-Elela et al. (2014). In VFCWS with mixed vegetation (croton \& Typha) $84.32 \%$ and $78.54 \%$ removal of BOD and COD was observed whereas, in unplanted only $31.08 \%$ \& $23.54 \%$ removal was witnessed (Chandrakanth et al. 2016). Studies conducted by Tiglyene et al. (2009) reported that CWS with Phragmites vegetation reported BOD removal of 37\% in control and $60 \%$ in test and COD removal of $74 \%$ in control and $61 \%$ in test. 


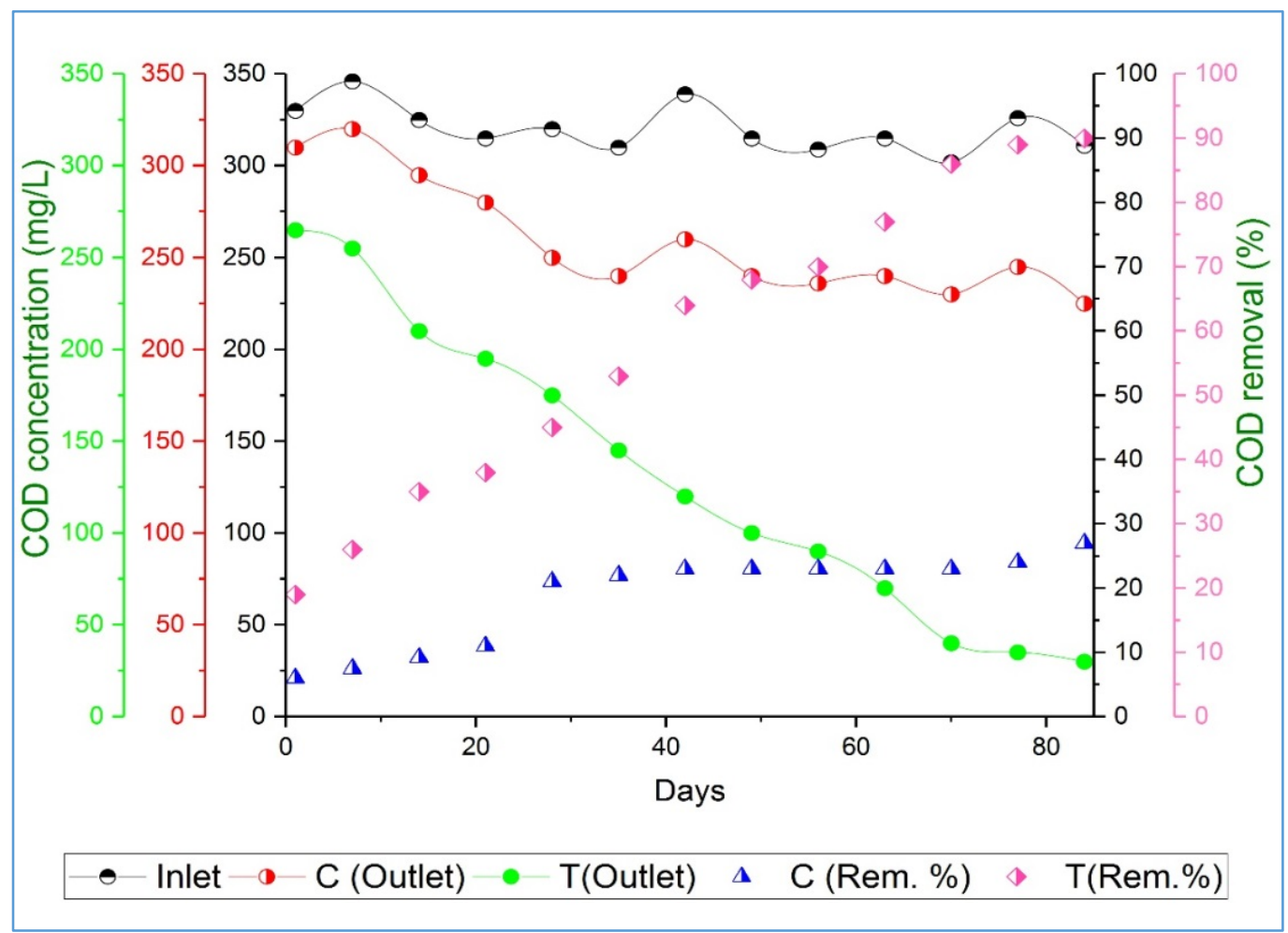

Figure 2.2 Efficiency of COD removal

Albalawneh et al. (2016) reported a removal efficiency of $47 \%$ and $38 \%$ of COD was achieved in control beds with fine media and coarse media. While, in beds planted with reeds $64 \%$ and $56 \%$ was attained in fine and coarse media. In VFCWS with Phragmites removal efficiency of BOD and COD were $84 \%$ and $75 \%$ for test and $37 \%$ and $29 \%$ for control (Abdelhakeem et al. 2016). Mustapha et al. (2018) stated that the removal efficiency of BOD and COD were $76 \%$ and $73 \%$ for test and $48 \%$ and $41 \%$ for control in VFCWS with Typha vegetation. Mello et al. (2017) reported COD removal of $60 \%$ in control and 67\% in CWS with Eichornia crassipes vegetation (Lima et al. 2018).

In our study, the removal efficiency of organics in planted bed is approximately 2.5 times higher than unplanted. In planted versus unplanted, vegetation facilitates organic removal. Stefanakis \& Tsihrintzis (2012) reported that vegetation played a significant role in the removal of organics. The efficiency to treat organics in unplanted control can be enhanced by adding bacterial consortium (Singh \& Patidar 2015).

\subsubsection{Efficiency of Nutrient Removal}

The concentration of TKN and TP in the inlet ranged from 24-30 and 4.2-5.2 mg/L respectively. The nutrient removal efficiency was increased in the integrated system. Results reveal that the removal efficiency of TKN and TP were $90 \pm 4 \%$ and $76 \pm 5 \%$ (test) and $30 \pm 6 \%$ and $14 \pm 8 \%$ (control) are depicted in Fig. $2.3 \& 2.4$ respectively. The concentration of TKN in the effluent was 18 and $2 \mathrm{mg} / \mathrm{L}$ in control and test respectively. The concentration of TP in the effluent was 3.8 and 1 $\mathrm{mg} / \mathrm{L}$ in control and test respectively. The higher removal efficiency of nutrients in planted beds is attributed by plant uptake. Root system plays a dynamic role by providing existence for diverse microbial community involved in nutrient removal. Plants stimulate the removal of nitrogen by activating the biochemical pathways via increase supply of oxygen. It is apparent that removal efficiency in planted beds are enhanced than unplanted ones.

The removal efficiency of TKN was $91 \%$ and $95 \%$ in control and test (Klomjek 2016). Mello et al. (2017) reported that TKN removal is directly influenced by plants with removal efficiency of $25 \%$ in control and 47\% in CWS with Eichornia crassipes vegetation. 
The $\%$ of nitrifying bacteria Nitrosomonas, Nitrosospira and Nitrospira in the planted beds was reported to be higher than unplanted ones (Wang et al. 2016). Root zone is the distinct region for enhancement of microbial population in CWS. Removal efficiency of phosphate in unplanted controls: 31.6 - 54.3\%, in Cyperus papyrus based CWS: 68.6 - 86.5\% and in Miscanthidium violaceum based CWS: 46.7-61.1\% was reported by Kyambadde et al. (2005). In VFCWS with Phragmites, removal efficiency of TP was 22\% and 17\% in unplanted (Abdelhakeem et al. 2016).

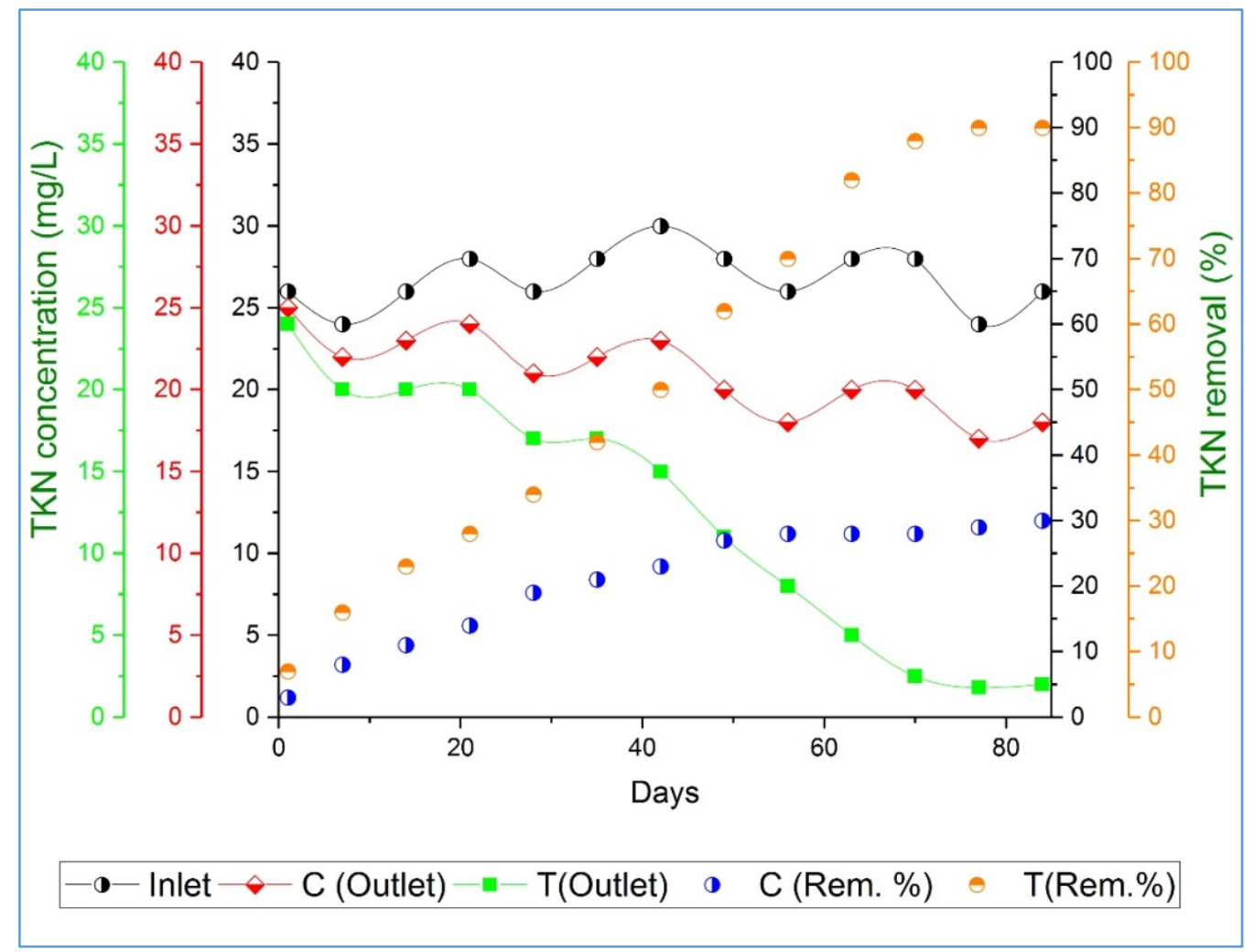

Figure 3.3 Efficiency of TKN removal

Albalawneh et al. (2016) reported a removal efficiency of 58\% and 35\% of TP was achieved in control bed with fine media and coarse media. While, in planted $75 \%$ and $61 \%$ was attained with fine and coarse media. Removal efficiency of TP in VFCWS with Typha and unplanted were $49 \%$ and 26\% (Mustapha et al. 2018) and 63.5\% and 52.7\% in test and control (Abou- Elela et al. 2014). Phosphate displaces hydroxyl ions in iron hydrous oxides. Phosphate and iron removal mechanisms are correlated (Vymazal 2005). Arivoli \& Mohanraj (2013) reported 83.51\% removal of TP in VFCWS with Typha angustifolia and $64.45 \%$ in control beds. The phosphorus and nitrogen uptake of Canna $\left(29.1 \mathrm{~g} \mathrm{P} / \mathrm{m}^{2}, 63.1 \mathrm{~g} \mathrm{~N} / \mathrm{m}^{2}\right)$, Phragmites $\left(30.91 \mathrm{P} / \mathrm{m}^{2}, 49.46 \mathrm{~g} \mathrm{~N} / \mathrm{m}^{2}\right)$ and Cyperus $\left(38.9 \mathrm{P} / \mathrm{m}^{2}\right.$, $82.33 \mathrm{~g} \mathrm{~N} / \mathrm{m}^{2}$ ) revealed that Cyperus is a better candidate than other two species in nutrient removal (Abou- Elela et al. 2014).

Lima et al. (2018) observed TKN removal of $82 \%$ and $87 \%$ in control and test units. In planted beds, about $26-71 \%$ of phosphate and $74 \%$ of total nitrogen was up taken by plants. TKN removal of $42 \%$ and $34 \%$ was witnessed in test and control units (Abou- Elela et al. 2014). 


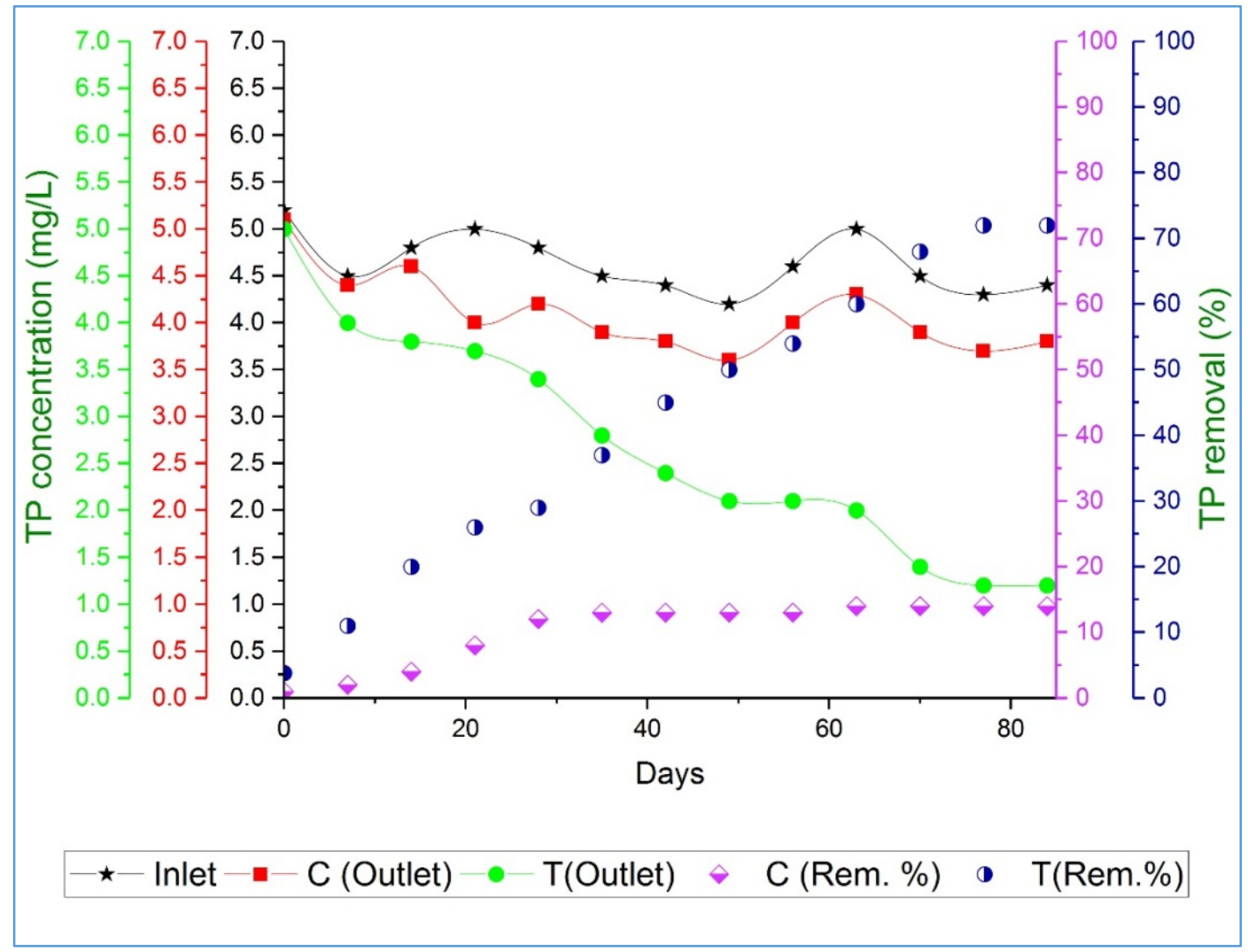

Figure 3.4 Efficiency of TP removal

The efficiency to treat nutrients in unplanted control can be enhanced by adding bacterial consortium (Singh \& Patidar 2015). Present study revealed that removal efficiency of phosphate and TKN in planted bed was approximately 5 and 3 times respectively than unplanted. Generally stated that removal of organics and nutrients in planted versus unplanted, planted units had higher removal efficiency than unplanted because plants play a critical role in removal mechanism (Zhao et al. 2009).

\subsubsection{Efficiency of Heavy Metal Removal}

The concentration of lead and iron in the inlet ranged from $0.164-0.263$ and $4.22-5.49 \mathrm{mg} / \mathrm{L}$ respectively. The heavy metals lead and iron were removed $100 \%$ in the test while, $70 \pm 4 \%$ and 57 $\pm 6 \%$ was achieved in control. The concentration of lead in the effluent was $0.06 \mathrm{mg} / \mathrm{L}$ and BDL in control and test respectively. The concentration of iron in the effluent was $2 \mathrm{mg} / \mathrm{L}$ and BDL in control and test respectively. Emergent plants in planted CWS, decreases the concentration of heavy metals in the effluent in an unravelling path when compared to unplanted control. The decrease in unplanted might be due to sorption or precipitation (Yadav et al. 2011). The results of lead and iron removal are presented in Fig. 2.5 \& 2.6 respectively.

The uptake of iron and lead by Cyperus alternifolius roots directly exposed to wastewater without substrate was $13.4 \%$ and $18.8 \%$. In CWS, the active layer contributing to heavy metal removal was till a depth of $10 \mathrm{~cm}$ where metals are converted to carbonate complex and stored in sediments. Treatment of wastewater released from iron and steel company in CWS attained 96.9\% removal of iron (Soda et al. 2012). 


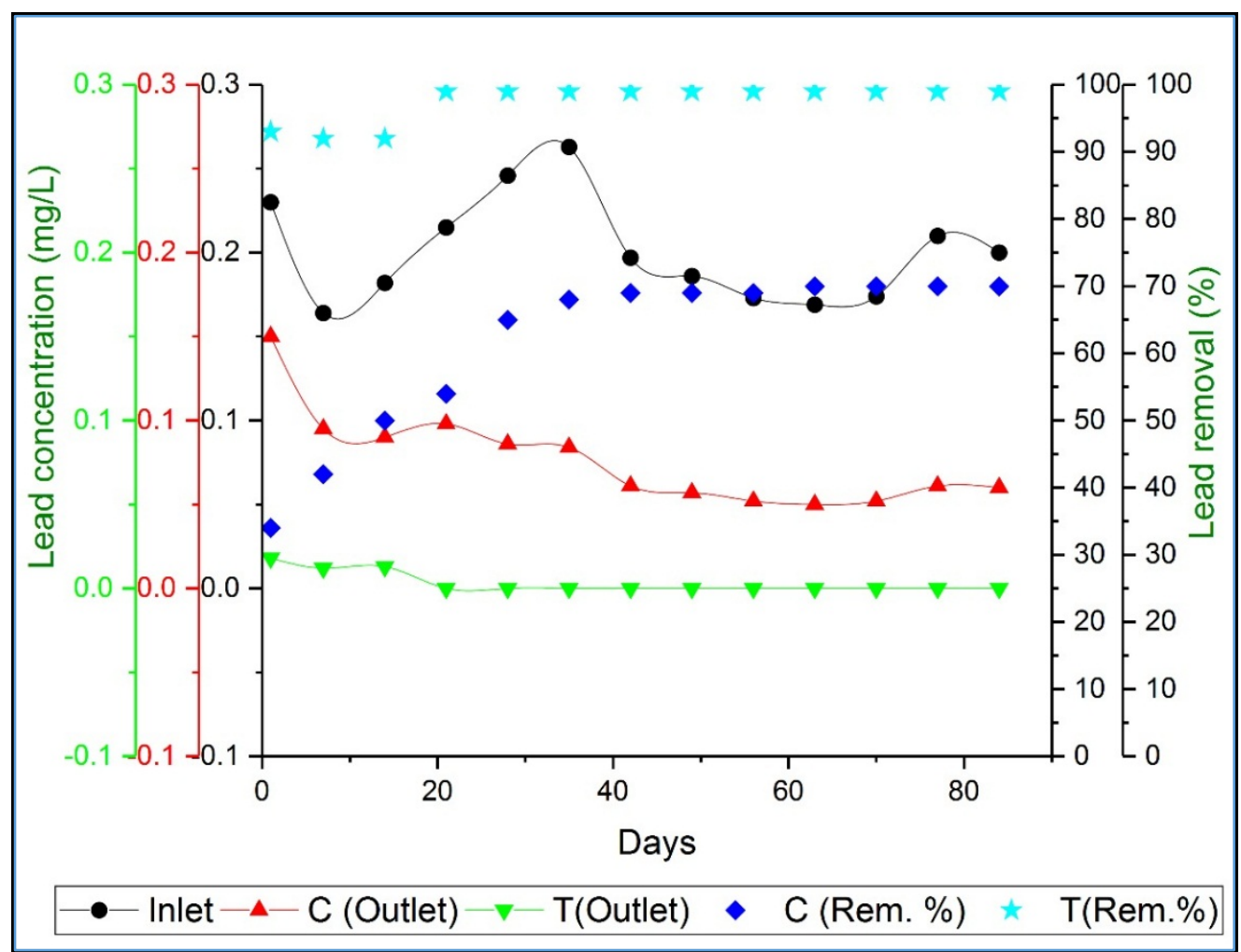

Figure 2.5 Efficiency of lead removal

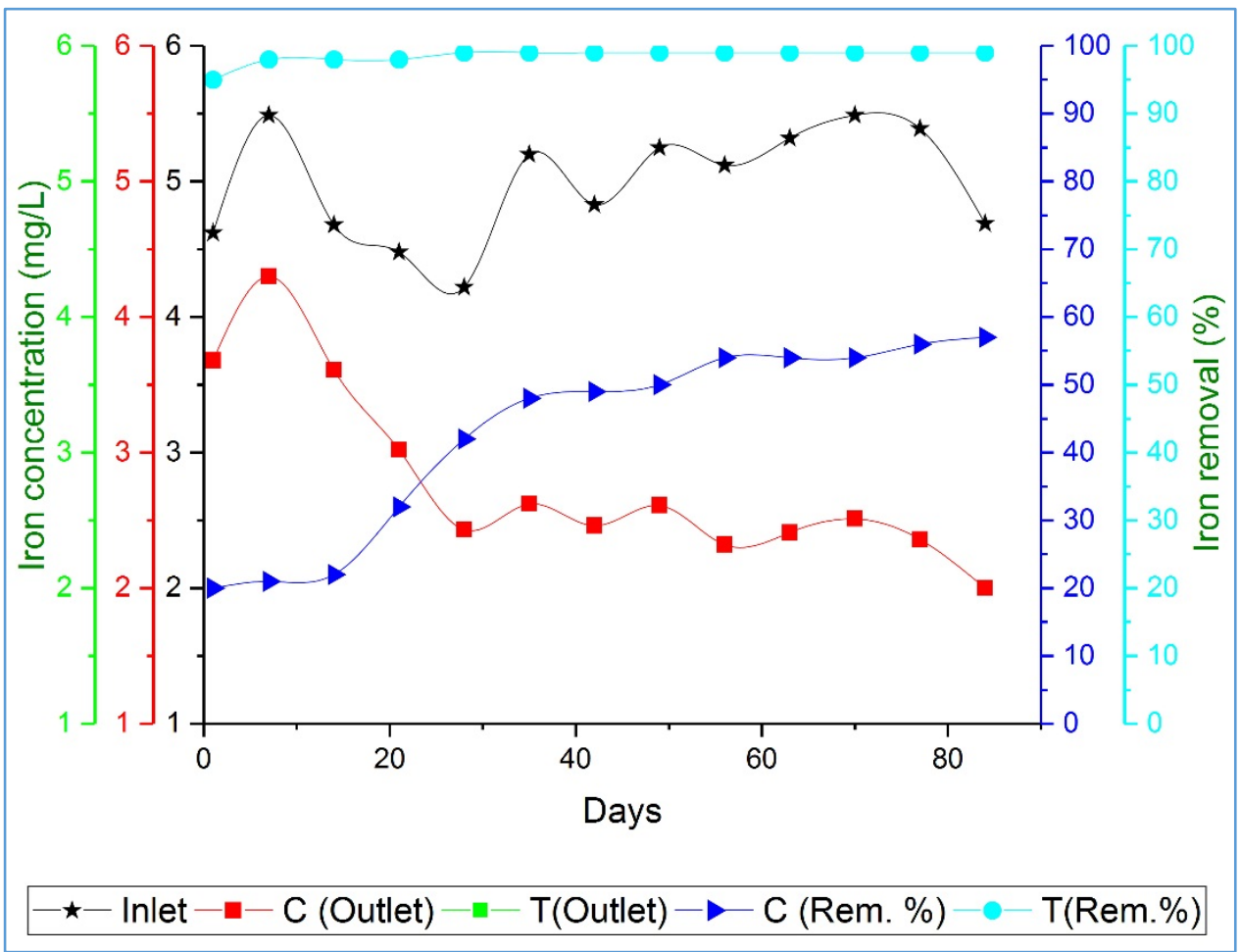

Figure 2.6 Efficiency of iron removal

The stimulating effect that aids heavy metal uptake by plants is production of root exudates which supports the bacterial population. Usharani \& Vasudevan (2017) reported that Cyperus releases root exudates upon heavy metal exposure that might aid in heavy metal uptake. One year study conducted by Gremion et al. (2004) concluded that in planted CWS, plants play a pivotal role in removal of heavy metals by releasing root exudates which enhance the bacterial population resulting in excellent performance of the system as a whole. Planted beds could efficiently remove $54 \%$ and $69 \%$ of cobalt and zinc and in unplanted 13\% and 30\% (Albalawneh et al. 2016). Integrated plantation of Typha 
angustifolia, Erianthus arundinaceus and Phragmites australis effectively removed 60-80\% of multiple metals and in unplanted $31-55 \%$ was observed. About $98 \%$ of iron removal could be achieved in CWS and the removal efficiency lasted for more than 5 years (Luca et al. 2011).

Chemical precipitation, rhizofiltration and microbe-metal interaction in rhizospere determines the mobility, bioavailability and bioaccumulation of iron. CWS with Phragmites vegetation removed $88 \%$ and $92 \%$ of lead and iron and Typha vegetation removed $87 \%$ and $95 \%$ whereas, in unplanted $78 \%$ and $88 \%$ was witnessed (Gikas et al. 2013). CWS planted with Carex pendula achieved 90\% removal of lead and very slight decrease was observed in unplanted (Yadav et al. 2011). The bio concentration of Cyperus alternifolius revealed that it exhibited higher removal efficiency of multiple metals (Soda et al. 2012). About $99 \%$ of chromium was removed in planted and unplanted but, the retention time in planted was 3 times lesser than unplanted (Tiglyene et al. 2009).

\subsubsection{Efficiency of Suspended and Dissolved Solids Removal}

The concentration of TSS in the inlet ranged from $320-359 \mathrm{mg} / \mathrm{L}$. In the present study $92 \pm 6 \%$ and $43 \pm 4 \%$ removal of TSS was attained in test and control respectively, presented in Fig. 2.7. The concentration of TSS in the effluent was 185 and $30 \mathrm{mg} / \mathrm{L}$ in control and test respectively. The major removal mechanism for TSS is sedimentation and filtration followed by aerobic and anaerobic microbial degradation (Manios et al. 2003). In the planted reed beds, the microbial degradation process might be enhanced as an increase in microbial growth is observed in planted beds than unplanted ones. Plants root acts as a substrate for increased microbial growth.

Mustapha et al. (2018) stated that the removal efficiency of TSS in VFCWS with Typha latifolia and unplanted were $92 \%$ and $40 \%$ respectively. Removal efficiency of $65 \%$ and $67 \%$ of TSS was achieved in control bed with fine media and coarse media. While, in bed planted with reeds $64 \%$ and $79 \%$ was attained in fine and coarse media (Albalawneh et al. 2016). TSS removal in CWS with Phragmites vegetation was in the range of (61-80\%) with an average of $75 \%$ and in unplanted $42 \%$ (Abdelhakeem et al. 2016).

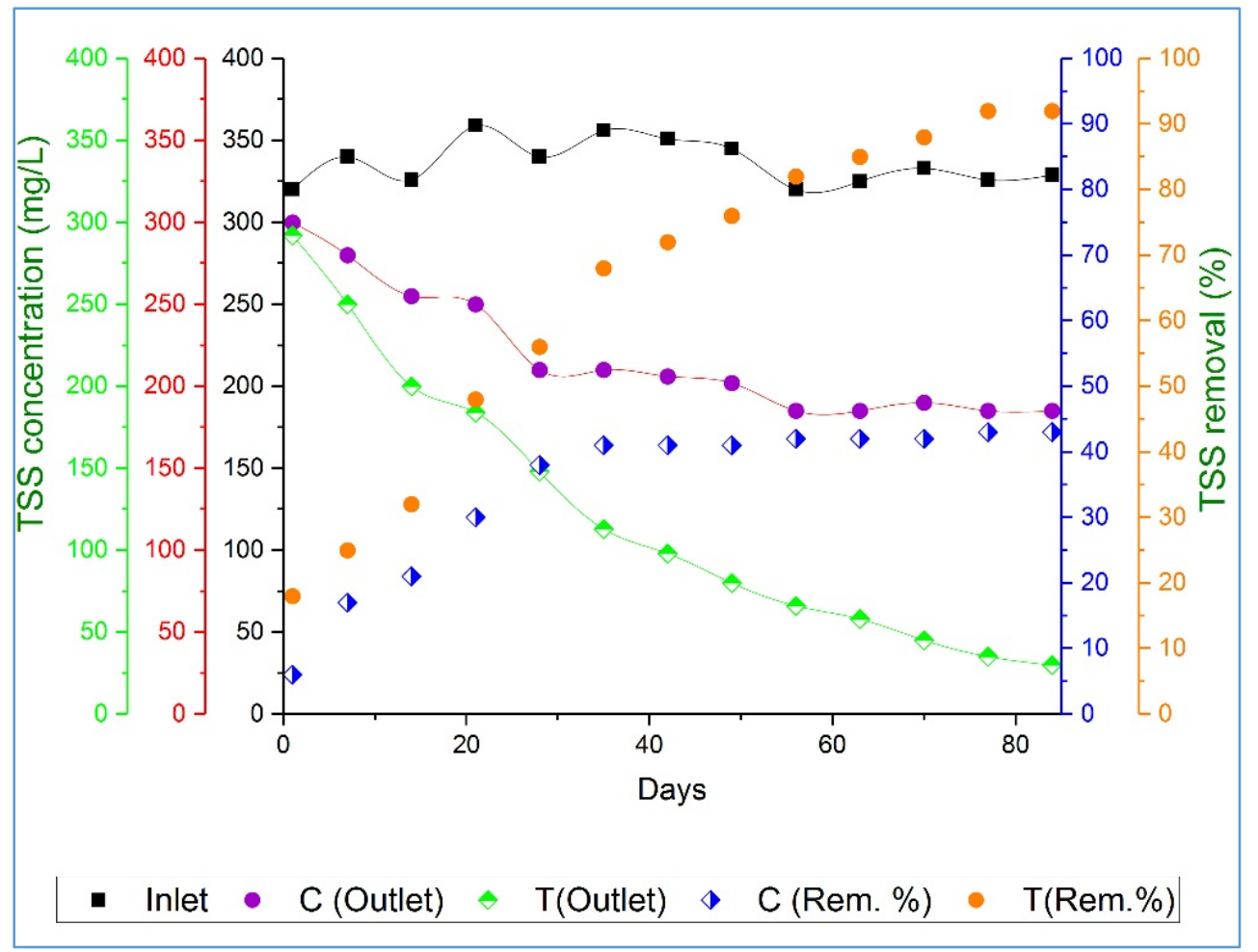

Figure 2.7 Efficiency of TSS removal

No significant change in TSS removal of planted (92\%) and unplanted (91\%) was reported by Abou- Elela et al. (2014). Karathanasis et al. (2003) reported more than $88 \%$ removal of TSS in CWS planted with Typha and 46\% in control. TSS removal of $73 \%$ and $65 \%$ was attained in test and control (Klomjek 2016). 


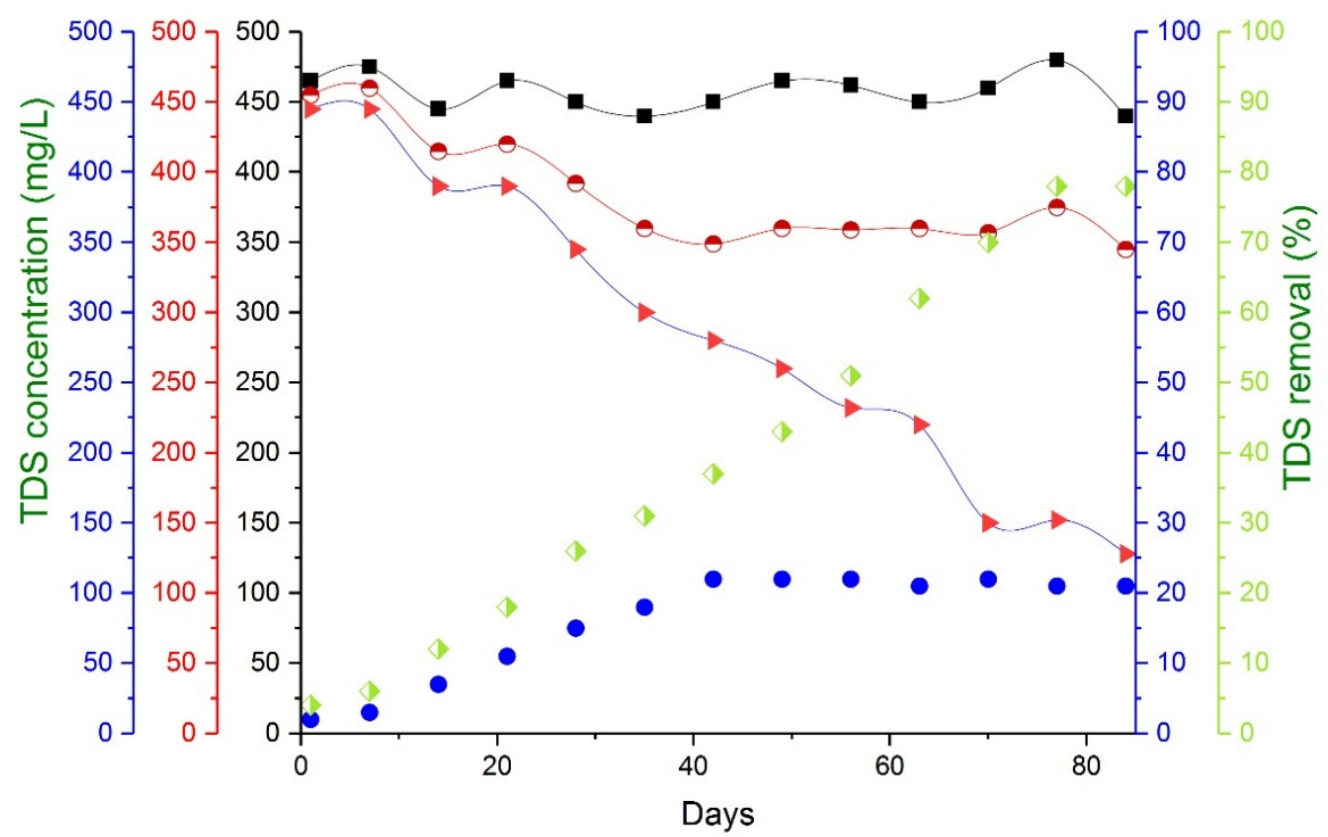

$\rightarrow-$ Inlet $-\mathrm{C}$ (Outlet) $\rightarrow \mathrm{T}($ Outlet $) \quad \bullet \quad \mathrm{C}($ Rem. \%) $\quad \mathrm{T}($ Rem.\%)

Figure 2.8 Efficiency of TDS removal

In our study $78 \pm 5 \%$ and $21 \pm 8 \%$ removal of TDS was achieved in test and control respectively which is depicted in Fig. 2.8. The concentration of TDS in the inlet ranged from 440-480 mg/L. The concentration of TDS in the effluent was 345 and $128 \mathrm{mg} / \mathrm{L}$ in control and test respectively. The activated carbon granules in the integrated system might have favoured an increase in TDS removal. In general, $77.7 \%$ of TDS can be removed in CWS, but addition of biochar as substrate could enhance the removal efficiency to $85 \%$ (Vidya Vijay et al. 2017).

Typha angustifolia in VFCWS had efficiently removed $84.66 \%$ and $67.26 \%$ of TDS in test and control (Arivoli \& Mohanraj 2013). Removal of TDS in VFCWS with croton (32.96\%), Typha (96\%) and unplanted (9.26\%) was observed by Chandrakanth et al. (2016).

The removal efficiency of sulphate and chloride were $69 \pm 6 \%$ and $68 \pm 4 \%$ in test and $27 \pm 8 \%$ and $21 \pm 7 \%$ in control are depicted in Fig. $2.9 \& 2.10$ respectively. The concentration of sulphate and chloride in the inlet ranged from $41-57$ and $40-50 \mathrm{mg} / \mathrm{L}$ respectively. The concentration of sulphate in the effluent was 31 and $13 \mathrm{mg} / \mathrm{L}$ in control and test respectively. The concentration of chloride in the effluent was 30 and $12 \mathrm{mg} / \mathrm{L}$ in control and test respectively. Oxidation of ammonia in the system might have favoured the removal of sulphate and chloride in the system. Biochemical oxidation of $\mathrm{NH}_{4}$ leads to decrease in salinity with $4.59 \%$ sulphate and $4.60 \%$ chloride removal. (Van Haandel \& Van der Lubbe 2012). 


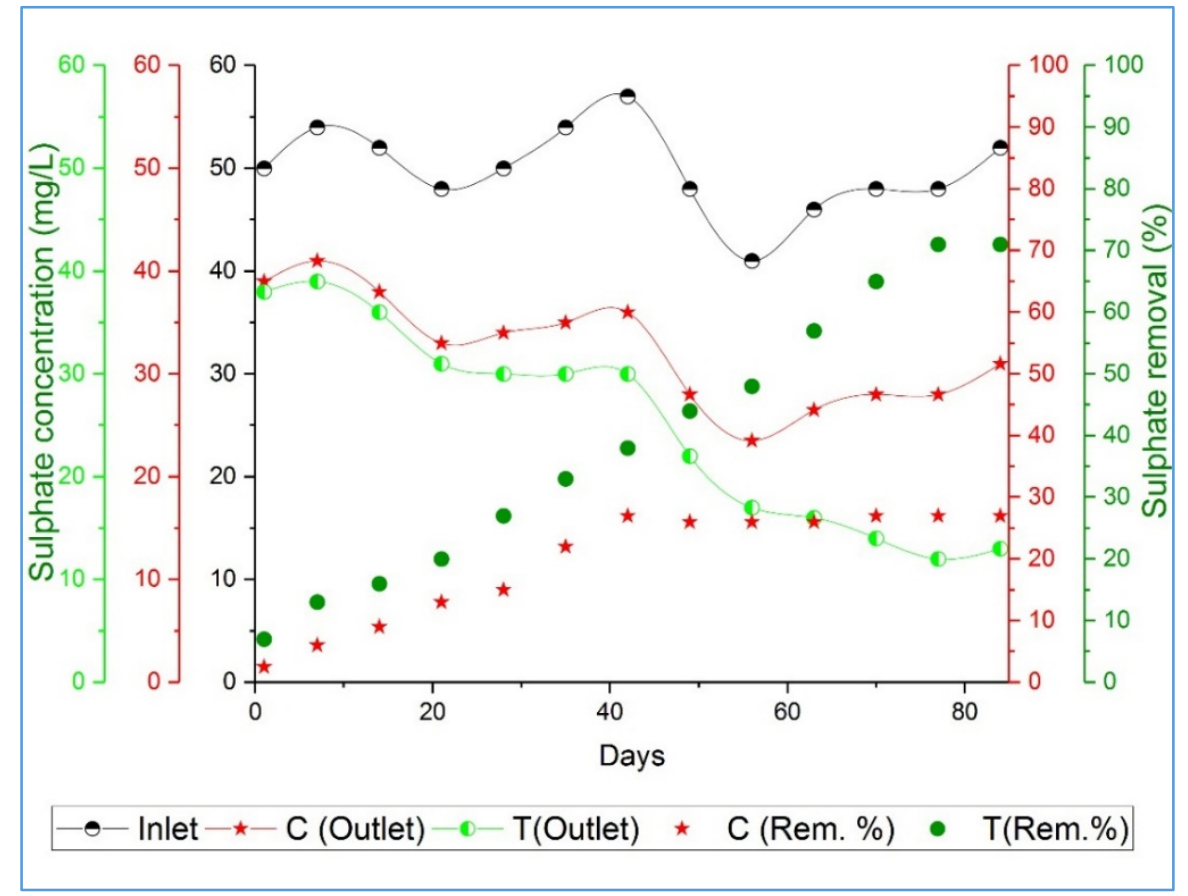

Figure 2.9 Efficiency of sulphate removal

About $94 \%$ of sulphate and $37.5 \% \mathrm{Cl}$ removal from municipal wastewater was attained in CWS with water Hyacinth (Olukanni \& Kokumo 2013). In hybrid CWS planted with Paspalidium flavidum $80.75 \%$ sulphate removal in domestic wastewater was attained (Sehar et al. 2013). TDS removal of $20 \%$ and $26 \%$ was reached in control and test (Klomjek 2016). Sulphate reduction accounted for organic matter removal. The removal of sulphate and chloride by ion chromatographic technique revealed $99.9 \%$ and $63.6 \%$ could be attained in CWS with Hymenachne grumosa vegetation (De Almeida et al. 2015).

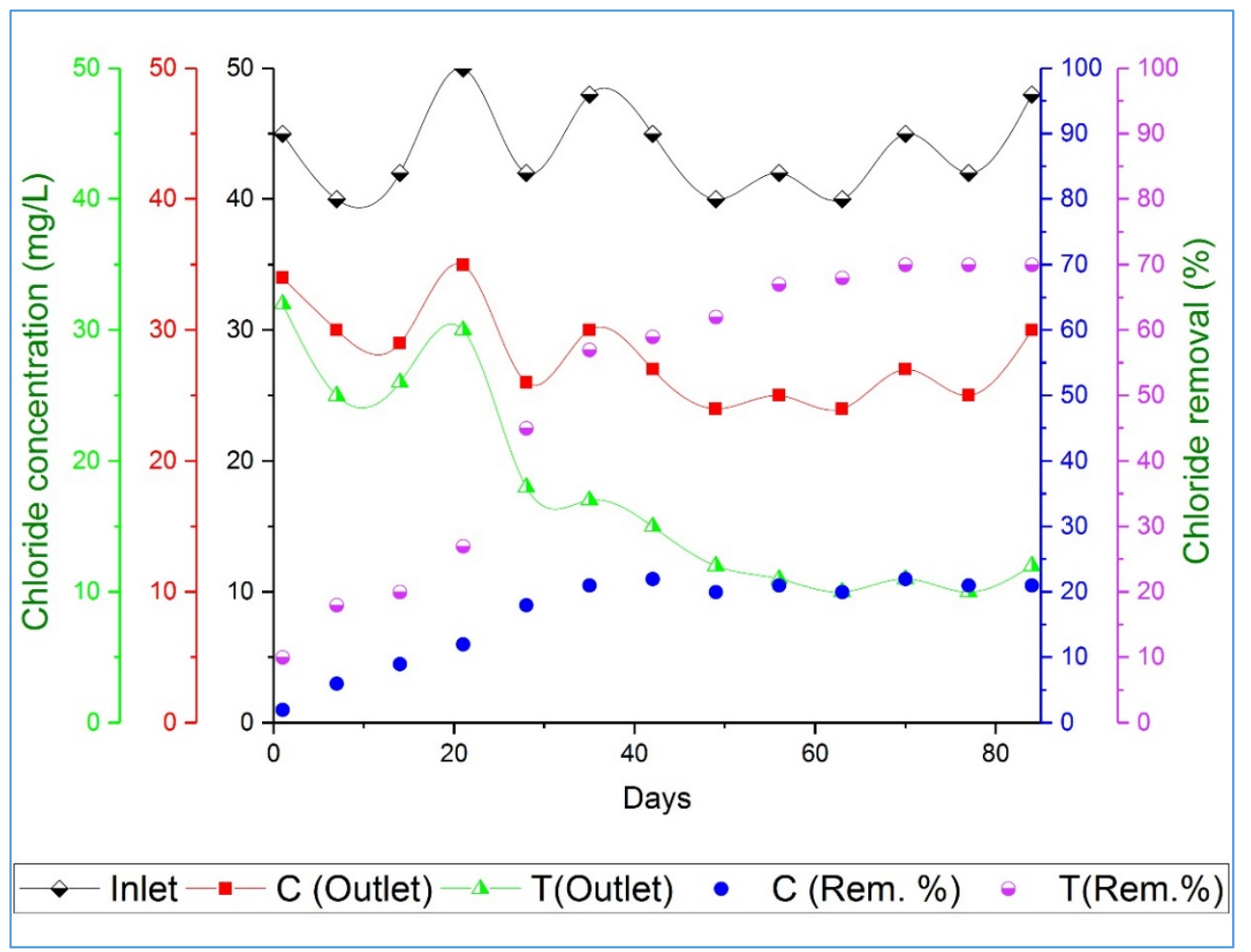

Figure 2.10 Efficiency of chloride removal 
Reduction of iron and sulphate are correlated. Plant derived organic carbon facilitates the removal of sulphate and chloride in CWS with vegetation and can be concluded that vegetation stimulates dechlorination and sulphate reduction (Chen et al. 2012).

\subsubsection{Efficiency of Coliform Removal}

The pathogen reduction in log removal for test and control units were 5.4 and 1.1 for T.C, 4.4 and 1.2 for F.C and 3 and 1 for E.coli. The inlet concentration of T.C, F.C and E.coli were 42.1x10 6 $6.3 \times 10^{8}, 4.9 \times 10^{5}-14.4 \times 10^{6}$ and $7.8 \times 10^{3}-3.8 \times 10^{5}$ respectively. Sustained removal of coliform were observed in the present study after polishing treatment via nanocomposite clay filter. The effluent achieved a quality of less than $1000 \mathrm{MPN} / 100 \mathrm{~mL}$ for T.C, and less than $500 \mathrm{MPN} / 100 \mathrm{~mL}$ for F.C and E.coli throughout the period of study. The results of log reduction of total coliform in control and test units are depicted in Fig. 2.11.

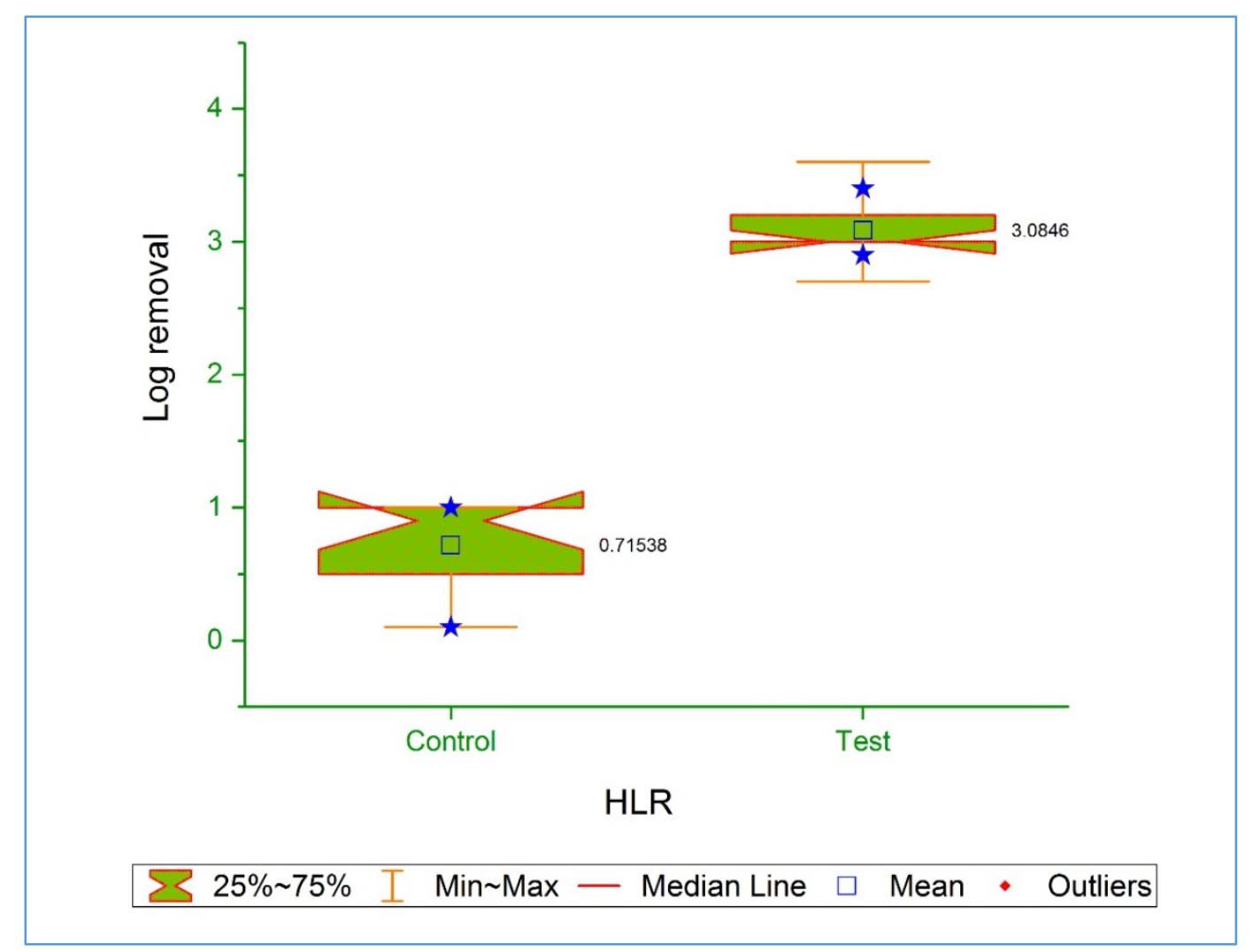

Figure 2.11 Efficiency of TC removal

Removal efficiency of one log removal is equivalent to $90 \%$ and $2 \log$ removal is equivalent to 99.9\%. Nano photo catalyst fluidised bed photo reactor system could achieve effluent quality suitable for irrigation (Brame et al. 2014). The results of log reduction of fecal coliform in control and test units are depicted in Fig. 2.12.

Maximum of more than $6 \log$ removal of E.coli was achieved in surface modified activated carbon filter media impregnated with silver NPs (Pal et al. 2006). 


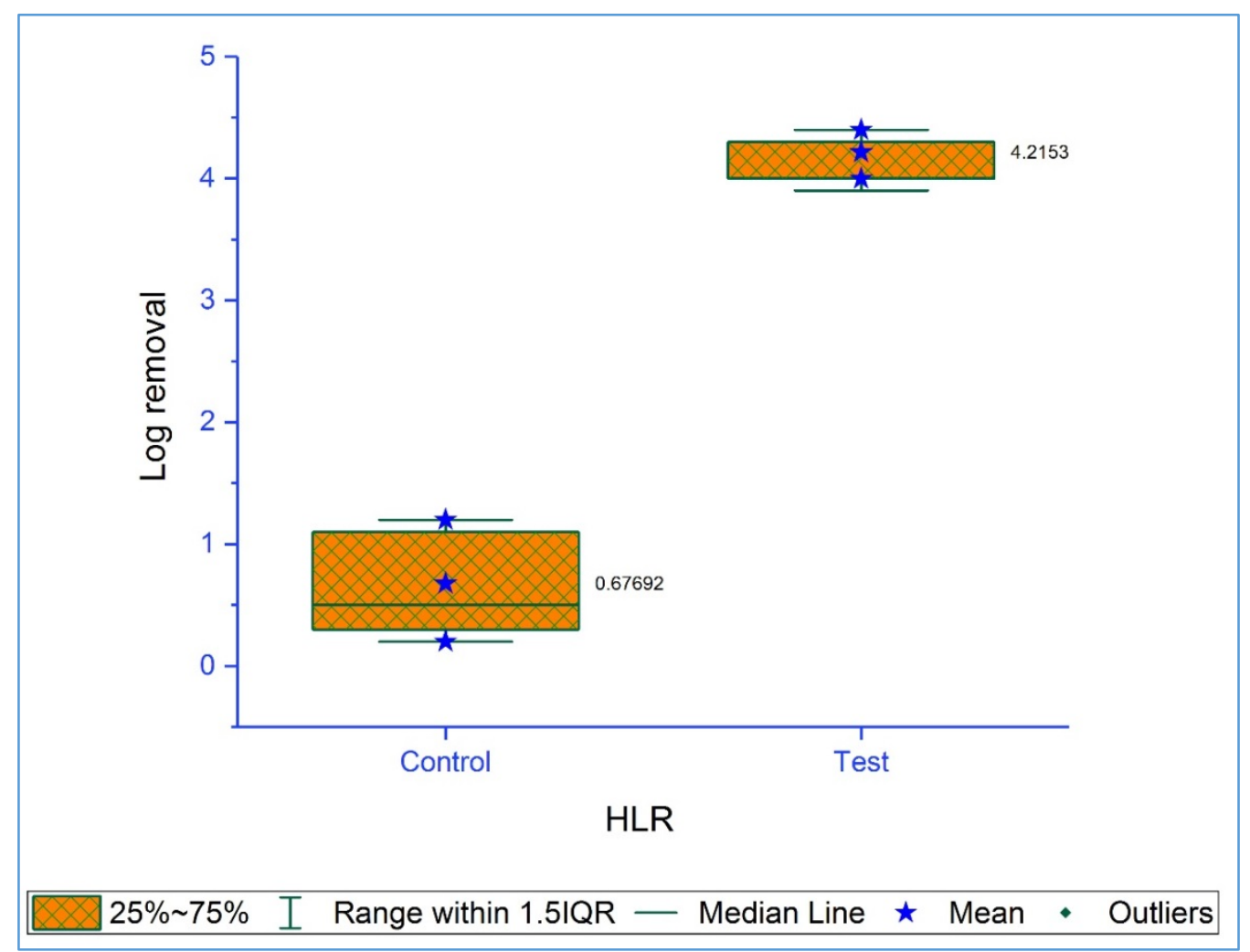

Figure 2.12 Efficiency of FC removal

Log reduction of 0.6 and 1.2 fecal coliforms was achieved in control bed with fine media and coarse media. While, in beds planted with reeds 1.2 and $0.9 \log$ reduction of fecal coliforms was attained in fine and coarse media (Albalawneh et al. 2016). Planted beds could attain 4 log removal while, 2-3 log removal in unplanted. Despite of $4 \log$ removal in planted, the effluent couldn't meet the national regulatory standards of discharge and requires an additional disinfection unit. Cyperus effectively removed T.C, F.C and E.coli than Phragmites and Canna (Abou- Elela et al. 2014). The results of $\log$ reduction of E.coli in control and test units are depicted in Fig.2.13.

In two stage or three stage hybrid system of CWS, maximum removal of coliform occurred in first stage with $2 \mathrm{log}$ reduction of TC, $1.91 \mathrm{log}$ reduction of F.C and $2.13 \mathrm{log}$ reduction of E.coli (Tuncsiper et al. 2012). Vacca et al. (2005) concluded that majority of reduction takes place in the first $20 \mathrm{~cm}$ with $\log$ reduction of 4.31 for T.C and 4.35 for E.coli. 


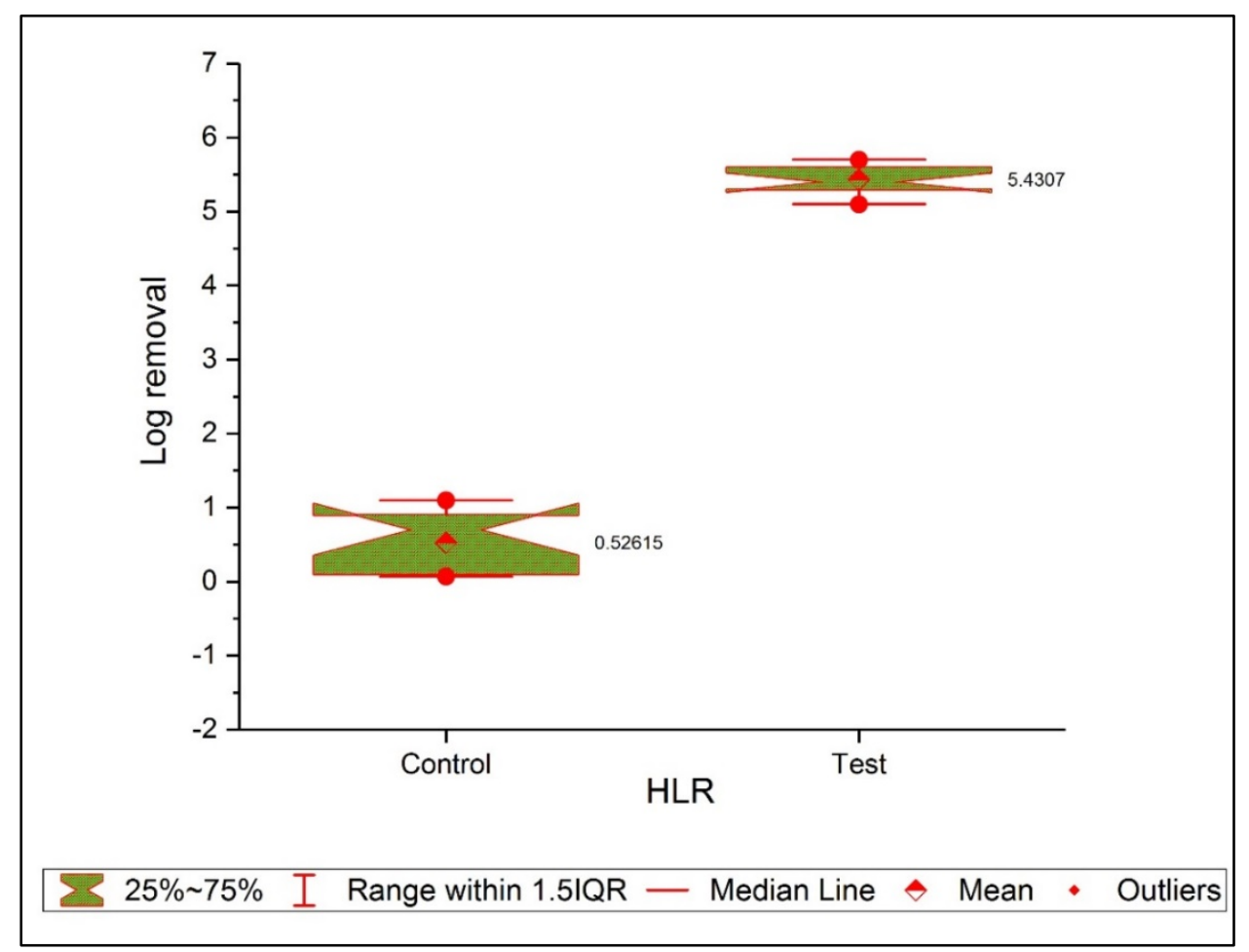

Figure 2.13 Efficiency of E.coli removal

CWS could achieve only $3 \log$ removal of E.coli and further treatment is required such that effluent can be utilised for irrigation. But in CWS 3-4 log reduction of T.C and E.coli is guaranteed for a running period of two years (Zurita \& Carreon-Alvarez 2015).

\subsubsection{Heavy Metal Accumulation in Plant and Reed Beds}

In the present study, accumulation of lead and iron in CWS revealed the accumulation pattern of reed bed $>$ below ground parts $>$ above ground parts. About two third of the cumulative concentration was retained in sediment and remaining was up taken by the plants. Roots retained the heavy metals and only meagre quantity was transferred to above ground biomass. The reason might be due to harvesting of plants within a limited time. Bio concentration factor (BCF) of lead and iron were 0.26 and 0.11 respectively. However longer duration of treatment might have increased the $\mathrm{BCF}$ and $\mathrm{TF}$ factor. But it is advisable to harvest plants in short duration to avoid much complications. Heavy metal accumulation in CWS is depicted in Fig. 2.13.

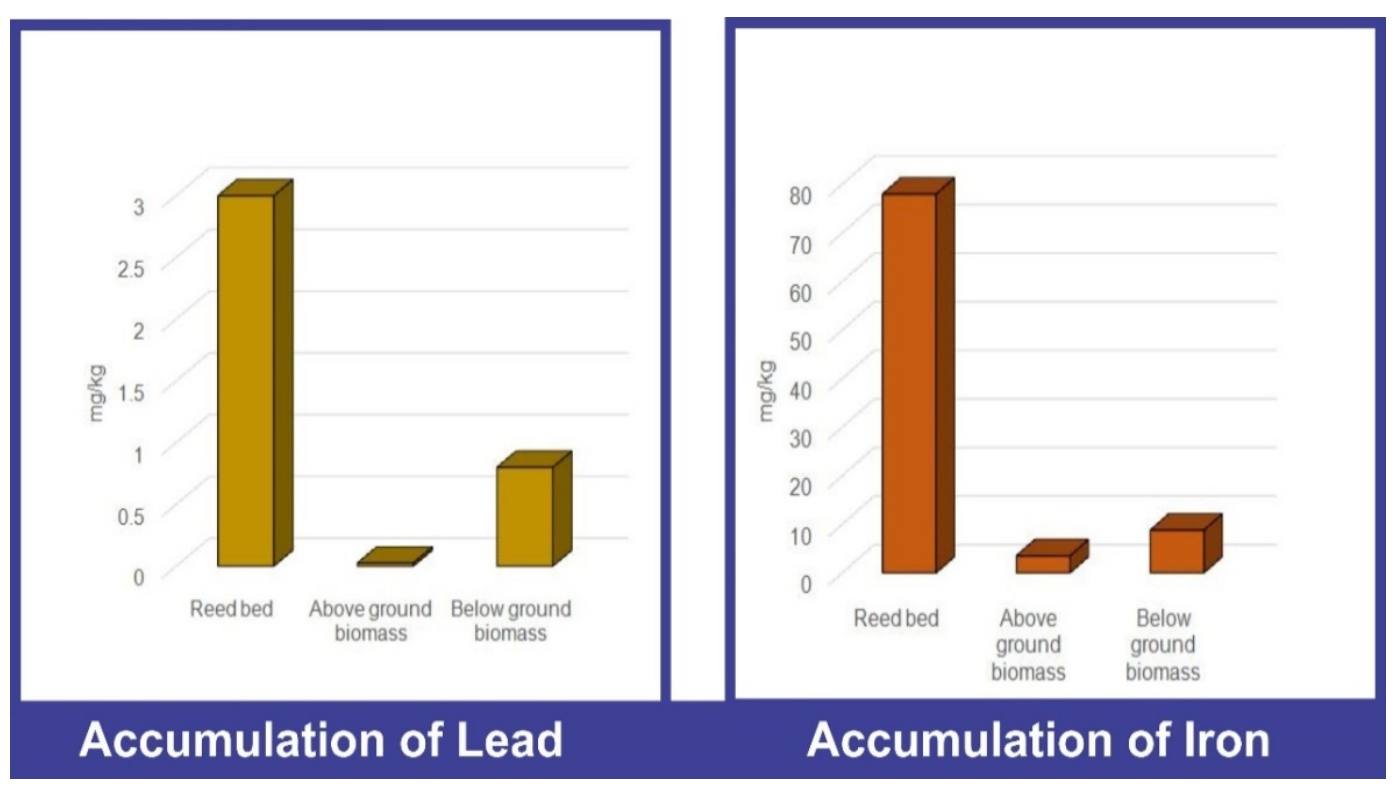

Figure 2.13 Accumulation of heavy metals 
The translocation factor (TF) of lead and iron were 0.03 and 0.4 respectively. TF $1>$ reveals that transportation of heavy metals to above ground part is less and is safe for disposal after harvest. The harvested culms can be utilized economically. Harvesting of shoots had a positive reciprocation for pollutant removal in CWS during summer (Yang et al. 2016). India, being a tropical country, harvesting might be preferred throughout the year without much seasonal fluctuation. Elemental analysis of the plant part: culm and root were carried out to confirm whether the harvested culm can be utilized economically and is safe for disposal. Elemental analysis of culm is depicted in Fig. 2.14. From the spectrum it was confirmed that only negligible quantity of lead is accumulated in culm.

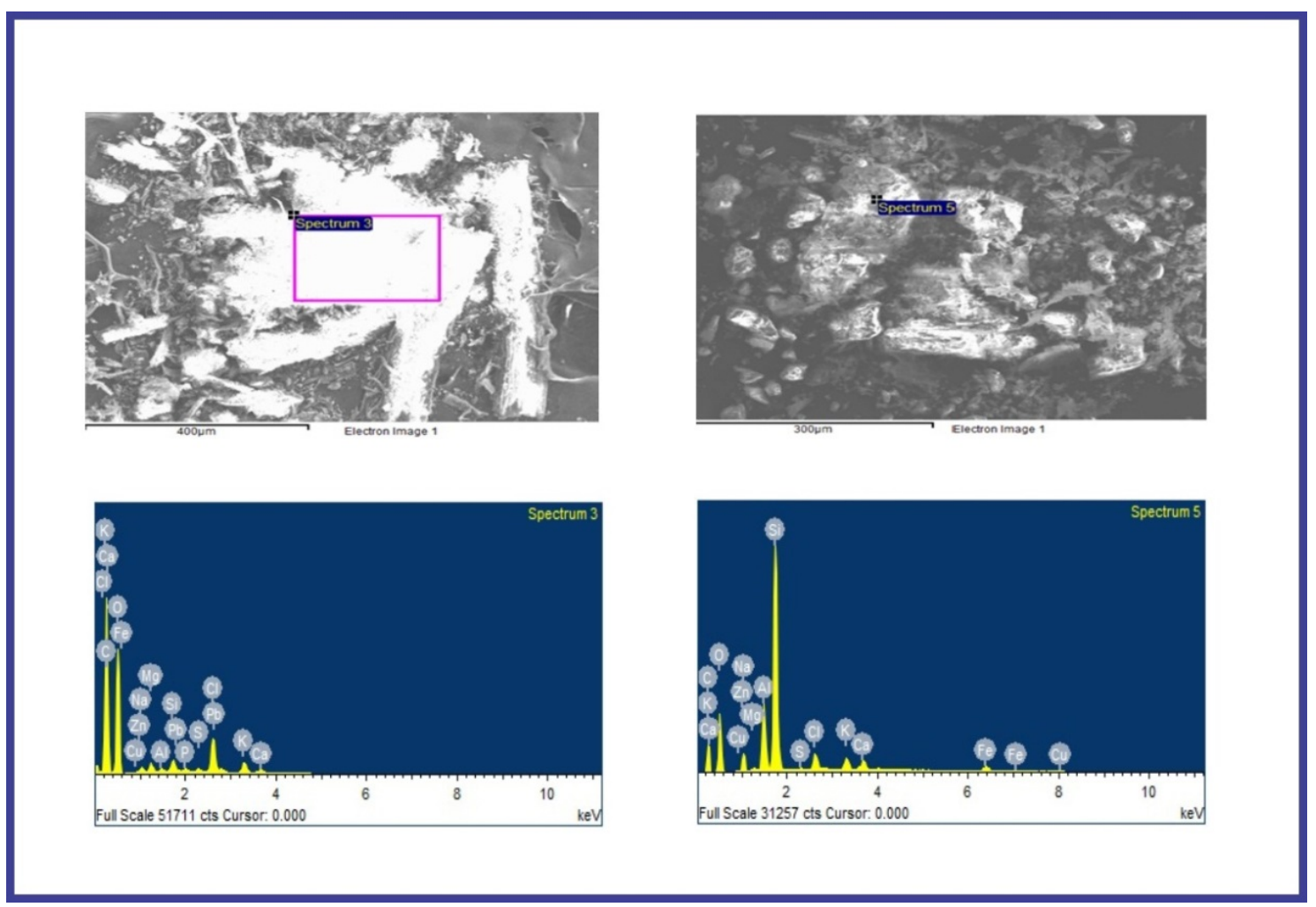

Figure 2.14 Elemental content in culm

Elemental analysis of root is depicted in Fig. 2.15. It revealed that the concentration of lead is comparatively higher in roots than culm and hence it is advisable to harvest the above ground bio mass and continue treatment after a break period. The micro flora in the reed bed might precipitate the metals into inert form without damaging the ecosystem. 


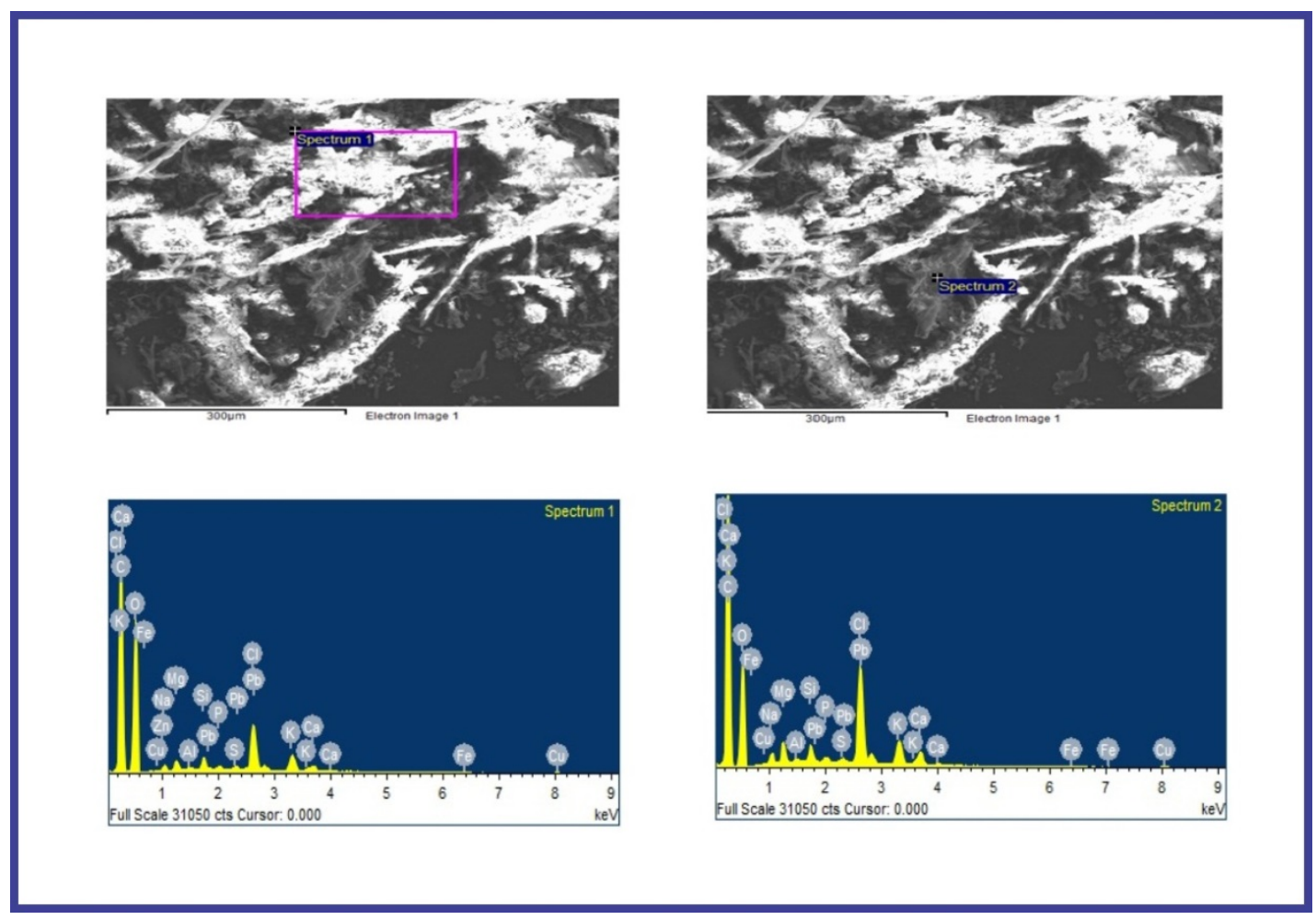

Figure 2.15 Elemental content in root

Our results correlate with some of the recent findings. Accumulation of heavy metals are more in the soil of CWS with plantation. Under tropical conditions, roots of Typha latifolia, Cyperus alternifolius and Cynodon dactylon accumulates highest concentration of iron and chromium than other parts of the plant. The accumulation pattern was roots $>$ leaves $>$ stem (Mustapha et al. 2018 a).

\subsubsection{Mass Balance of Heavy Metals}

The above ground biomass of Cyperus was $4.8 \mathrm{~kg} / \mathrm{m}^{2}$. In a study conducted by Abou-Elela et al. (2014), it was concluded that the biomass of Cyperus was greater than Canna and Phragmites. The standing biomass of Cyperus at the end of the experiment was $2.6 \mathrm{~kg} / \mathrm{m} 2$ with moisture content of $43 \%$. The accumulation of lead in reed bed and plants accounted to $63 \%$ and $33 \%$ respectively while, that of iron $58 \%$ and $38 \%$. In the culm, $6 \%$ and $29 \%$ of lead and iron were accumulated with a concentration of $250 \mu \mathrm{g} / \mathrm{kg}$ of lead and $3.5 \mathrm{mg} / \mathrm{kg}$. The remaining $4 \%$ might have been accumulated in the clay discs and negligible quantity discharged in effluents.

At the end of the experiment, porosity of CWS and nanocomposite clay filter decreased by $3 \%$ and $1 \%$ respectively. The effluent quality complied with standards of discharge for irrigation and inland surface water regulated by $\mathrm{CPCB}$, India. The quality of the effluent was cross checked with multiple linear regression analysis with BOD as dependent variable. R2 value of 0.991 and an adjusted R2 value of 0.978 was obtained deeming it as a good fit with significance of .000. For degree of freedom $(7,5), F=76.971$. The Durbin-Watson test of autocorrelation $d=2.279$ between the two critical values of $1.5<\mathrm{d}<2.5$. Thus it can be assumed that there is no first order linear autocorrelation in multiple linear regression data. The independent variables were statistically significant with $\mathrm{p}<$ 0.0005 . The overall regression model is a good fit of the data.

\section{Materials and Method}

\subsection{Optimisation of HLR in CWS}

The HLR of the CWS planted with Cyperus alternifolius was optimised applying first order kinetics. The effect of HLR on removal efficiency was examined over a period of 16 weeks at four different hydraulic loading rates: $28 \mathrm{~mm} / \mathrm{d}(20 \mathrm{~L} / \mathrm{d}), 56 \mathrm{~mm} / \mathrm{d}(40 \mathrm{~L} / \mathrm{d}), 84 \mathrm{~mm} / \mathrm{d}(60 \mathrm{~L} / \mathrm{d})$ and 
$112 \mathrm{~mm} / \mathrm{d}(80 \mathrm{~L} / \mathrm{d})$. Hydraulic retention time (HRT) of respective HLR was calculated theoretically from the formulae.

$$
\mathrm{HRT}=\frac{\text { Volume of wetland x porosity }}{\text { Flow rate }}
$$

Kadlec \& Wallace (2009) proposed the following equation for areal removal rate constant and the same equation was applied.

$$
\ln [(\mathrm{C} \text { (effluent) / C (influent) })]=-\mathrm{K}_{\mathrm{A}} / \mathrm{q} \text {. }
$$

Where $\mathrm{K}_{\mathrm{A}}$ is the areal removal rate constant in $\mathrm{m} \mathrm{d}^{-1}$ and $\mathrm{q}$ is the hydraulic loading rate in $\mathrm{m} \mathrm{d}^{-1}$.

The following equation for volumetric removal rate constant proposed by Reed et al. (1995) was applied.

$$
\ln [(\mathrm{C} \text { (effluent }) / \mathrm{C} \text { (influent }))]=-\mathrm{K}_{\mathrm{v}} \mathrm{t} .
$$

Where $K_{v}$ is the volumetric removal rate constant in $\mathrm{d}^{-1}$ and $t$ is the hydraulic retention time in the wetland. The formulas used for efficiency $\%$ and Mass removal rate are presented.

$$
\text { Removal efficiency } \%=C \text { (influent) }-\mathrm{C} \text { (effluent) x100/ C (influent)..... Eq.(2.3) }
$$

Where $\mathrm{C}$ represents concentration in $\mathrm{mg} / \mathrm{L}$.

Mass removal rate was calculated using the formula

$$
\mathrm{r}=\mathrm{q}(\mathrm{C} \text { (influent })-\mathrm{C}(\text { effluent }))
$$

Where $\mathrm{q}$ is the hydraulic loading rate in $\mathrm{m} \mathrm{d}^{-1}$. Mass removal rate is expressed in $\mathrm{g} \mathrm{m}^{-2} \mathrm{~d}^{-1} \cdot \mathrm{q}=\mathrm{Q} / \mathrm{A}$. where $\mathrm{Q}$ is the flow rate through the wetland and $\mathrm{A}$ is the area of the wetland. The disinfection

\subsection{Optimisation of clay disc for disinfection}

Clay discs were synthesised using potters clay, cuprous nanoparticle, montmorillonte nanoclay and paddy husk in the ratio 8:1:1:1. Optimisation studies were conducted in lab scale to enumerate the disinfection ability of clay discs on E.coli, as it is considered as an indicator organism. Pure cultures of E.coli inoculum was diluted with phosphate buffer until the optical density of the culture at $600 \mathrm{~nm}$ read as $1 \mathrm{~nm}$ and it corresponds to $5 \log$ CFU/ $100 \mathrm{ml}$ in pour plate technique.

The clay discs were immersed in water and soaked for 1 hour to ensure saturation and removal of internal air bubbles. Disinfection studies in batch and continuous were performed in sterile column (PVC pipe) packed with varied number of clay discs at different flow rates: $5 \mathrm{~mL} / \mathrm{min}, 10 \mathrm{~mL} / \mathrm{min}$, $15 \mathrm{~mL} / \mathrm{min}$ and $20 \mathrm{~mL} / \mathrm{min}$. The lower end of the PVC pipe was tapered with reduction valves and fitted with an outlet for the collection of effluent. The tapering part of the column was filled with coconut shell activated carbon granules as gap filler and is reported to remove organics, chlorine and malicious odours. Activated carbon does not possess disinfection property (Rodriguez 2001). Thus the results of disinfection efficacy relies only on the performance of clay disc. The volume of the clay disc was determined based on the optimised HLR of the CWS. The experimental set up is shown in Fig. 3.1. 


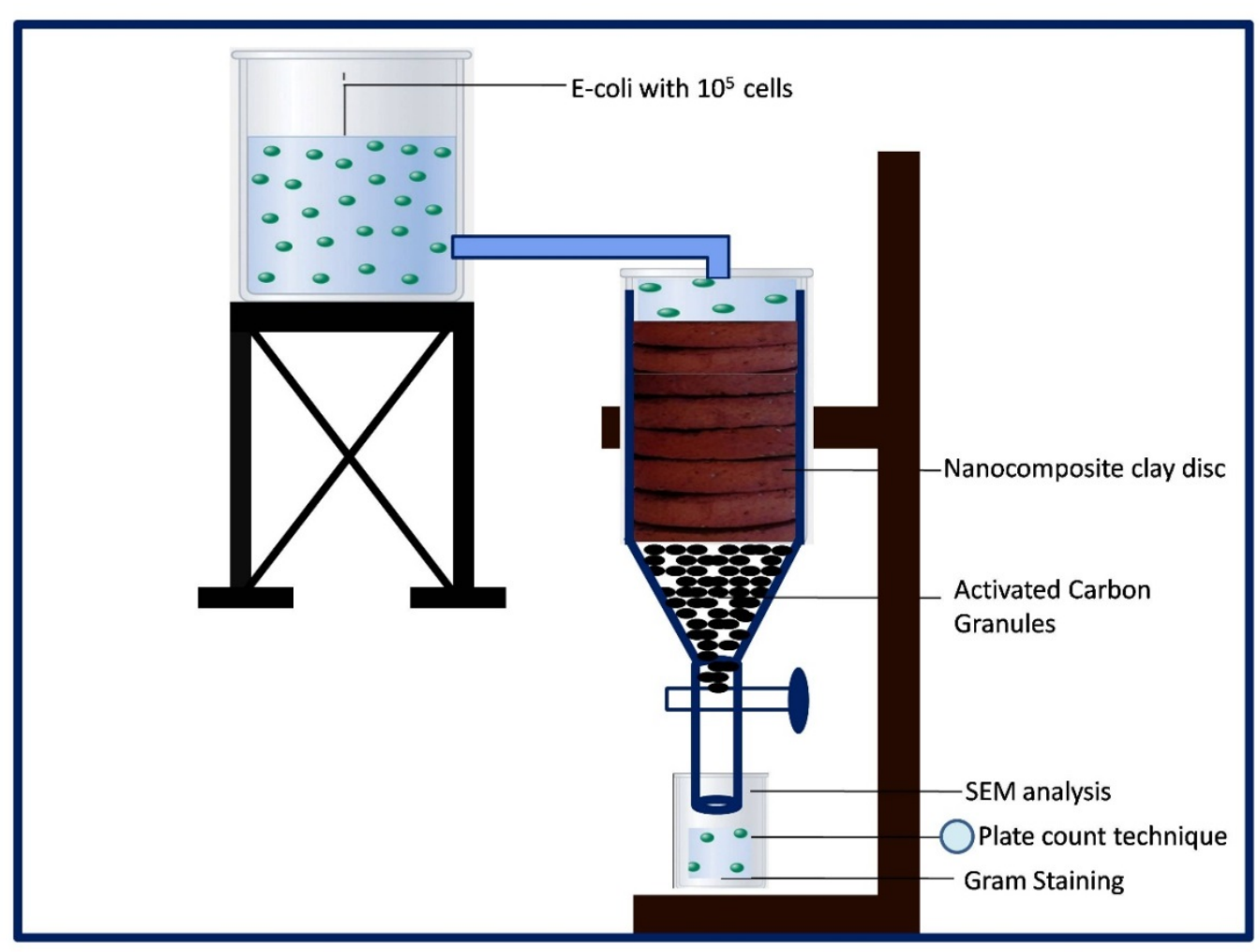

Figure 3.1 Experimental set up for disinfection studies

Integration of CWS with nanocomposite clay filter was experimentally set up such that the effluent from the constructed wetland was made to pass through the column filled with clay discs as a polishing treatment for disinfection and is presented in Fig. 3.2. The Constructed wetland unit planted with Cyperus alternifolius was integrated with nanocomposite clay disc packed in PVC column pipe. The lower end of the column was tapered with reduction valves and fitted with an outlet for the collection of effluent. The tapering part of the column was filled with coconut shell activated carbon granules. The flow of water into the integrated system was fixed as $60 \mathrm{~L} / \mathrm{d}(84 \mathrm{~mm} /$ day), based on optimisation studies. The column was packed with 32 clay discs to match the flow in the system. 


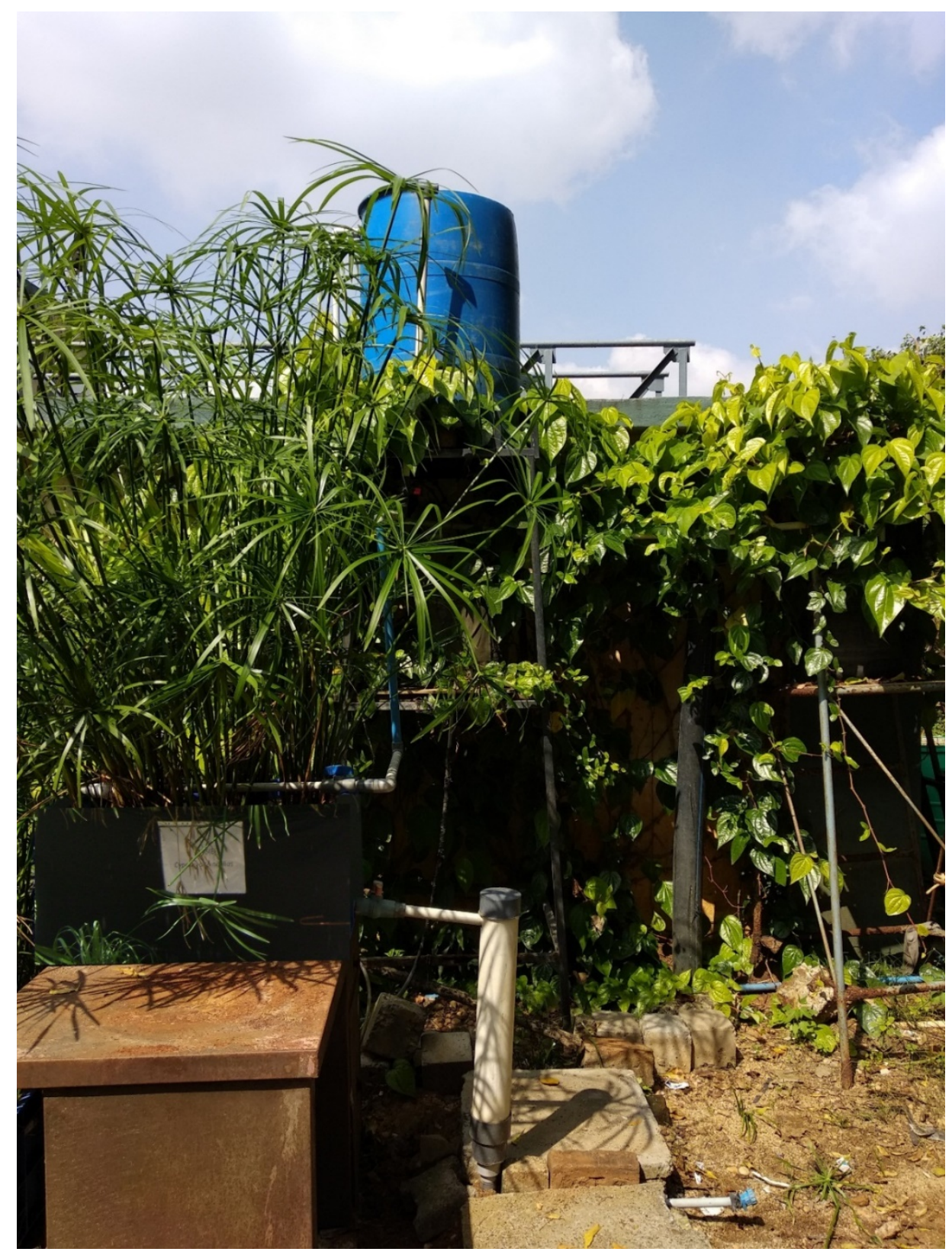

Figure 3.2 Integration of CWS tailed by nanocomposite clay disc filter

The same conditions were installed for control CWS (without plants) whose outlet was fitted with a column packed with 32 discs (without nanoparticles). Plants and nanoparticles individually and composite are capable of reduction of organics, nutrient from sewage. Hence both was avoided in controlThe inlet and outlet samples were collected weekly once and analysed for BOD, COD, TKN, phosphate, TSS, TDS, sulphate, chloride, lead, iron and MPN tests for total coliform, faecal coliform and E. coli were carried out in triplicates according to APHA procedure. The experiment was carried out for a period of 12 weeks because maximal growth of plants and constant removal rate was attained within the specified time so that plants can be harvested.

\subsection{Statistical Analysis}

The results of the research presented in table are provided as mean \pm S.D calculated in excel 2010. The results presented in graph are average of triplicates run in software Origin 2018. Statistical analysis of the effluent in the final set-up was carried out in multiple regression analysis in SPSS software version 16. BOD was taken as the dependent variable and parameters: COD, TKN, TP, TSS, TDS, $\mathrm{Cl}$ and $\mathrm{SO}_{4}$ were taken as independent variable with sample size of 12 . Confidence level of $95 \%$ was specified for the regression. The model was tested by investigating values of: $\mathrm{R}^{2}$, adjusted $\mathrm{R}^{2}$, significant $\mathrm{F}$ and $\mathrm{p}$ values. The Dubinson-Watson test for automated correlation was analysed. 


\section{Conclusion}

Among the diverse existing wastewater treatments schemes, CWS secures a peculiar place for its aesthetic value in addition to low cost maintenance. The optimal HLR for VFCWS planted with Cyperus alternifolius was $84 \mathrm{~mm} / \mathrm{d}(60 \mathrm{~L} / \mathrm{d})$ which achieved discharge quality of all parameters except pathogen removal. Vegetation is the major factor contributing the removal of organics and nutrients. The dynamic role of microbes in removal of organics, nutrients and heavy metal removal is inevitable and secures a noteworthy place in CWS. A small integrated unit can be installed in tourist spots because, CWS serves as a habitat for the macro fauna in and around the system providing biodiversity from ecological benefit point of view. The integration of CWS with nanocomposite filter is a novel idea and the outcome of the research is astounding.

The outcome of the research ended with the discharge of effluent with $10 \mathrm{mg} / \mathrm{L}, 30 \mathrm{mg} / \mathrm{L}$, $35 \mathrm{mg} / \mathrm{L}, 2 \mathrm{mg} / \mathrm{L}$, and $1.0 \mathrm{mg} / \mathrm{L}$ of BOD, COD, TSS, TKN and phosphate. With a close concern to coliform removal, less than $1000 \mathrm{MPN} / 100 \mathrm{~mL}$ for TC and less than $500 \mathrm{MPN} / 100 \mathrm{~mL}$ for FC and E.coli was achieved during the experimental period. The integration of clay disc not only improved the quality of effluent with respect to coliforms but also aided in the enhanced removal of other pollutants: organics, nutrients and heavy metals. Clay is a natural adsorbent and acts as a filtering mechanism. Moreover, montmorillonite is reported as an efficient adsorbent of pollutants in wastewater treatment. The pinnacle point of the research is that nanocomposite clay filter is a separate component that can be integrated with any existing system to eliminate pathogen. Cyperus alternifolius is a promising plant in CWS. The uptake of heavy metals in the above ground parts is lesser than the below ground part. The above ground biomass can be harvested and utilised economically. The problem of withering leaves was not observed till maximal growth of 5-6 feet neglecting the fear of adding nutrients back in to the system. Crisply to conclude in a nut shell, the outcome of the research ended up in achieving the goal. Focus can still more be done on nanocomposite clay discs for extrapolation in large scale however, this is just an initiative.

\section{References}

[1] Abdelhakeem, SG, Aboulroos, SA \& Kamel, MM 2016, 'Performance of a vertical subsurface flow constructed wetland under different operational conditions', Journal of Advanced Research, vol.7, no.5, pp.803-814.

[2] Abou- Elela, SI, Golinelli, G, El-Tabl, AS \& Hellal, MS 2014, 'Treatment of municipal wastewater using horizontal flow constructed wetlands in Egypt', Water Science and Technology, vol.69, no.1, pp. 38-47.

[3] Albalawneh, A, Chang, TK, Chou, CS \& Naoum, S 2016, 'Efficiency of horizontal sub-surface flow constructed wetland treatment system in an arid area', Water, vol.8, no.51, pp. 1-14.

[4] Arivoli, A \& Mohanraj R 2013, 'Efficacy of Typha angustfolia based vertical flow constructed wetland system in pollution reductant of domestic wastewater' International Journal of Environmental Science, vol.3, no.5, pp. 1497.

[5] Brame, J, Fattori, V, Clarke, R, Mackeyev, Y, Wilson, LJ, Li, Q \& Alvarez, P 2014, 'Water disinfection using nanotechnology for safer irrigation: A demonstration project in Swaziland', Environmental Engineer and Scientist, vol.50, no.2, pp.40-46.

[6] Chandrakanth, G, Srimurali M, Vivek Vardhan, CM 2016, 'A study on domestic wastewater treatment by pilot-scale constructed wetlands', International Journal of Chemtech Research, vol.9, no.06, pp.376-383.

[7] Chen, Z, Wu, S, Braeckevelt, M, Paschke, H, Kastner, M, Koser, H \& Kuschk, P 2012, 'Effect of vegetation in pilot-scale horizontal subsurface flow constructed wetlands treating sulphate rich groundwater contaminated with a low and high chlorinated hydrocarbon', Chemosphere, vol.89, no.6, pp.724-731. 
[8] Collison, RS \& Grismer, ME 2013, 'Nitrogen and COD removal from domestic and synthetic wastewater in subsurface-flow constructed wetlands', Water Environmental Research, vol.85, no.9, pp.855-862.

[9] De Almeida, M, Vargas-Zerwes, F, Ferreira-Bastos, L, da Costa, AB, de Souza-Schneider, R.D, C, Machado, E.L \& Kohler, A 2015, 'Cation and anion monitoring in a wastewater treatment pilot project', Journal of the Faculty of Engineering at the University of Antioquia, no.76, pp.82-89.

[10] Environmental Protection Agency (EPA) 2015, Alternative disinfectants and oxidants guidance manual. Available from <http://www.epa.gov/ogwdw/mdbp/ alternative disinfectants guidance>

[11] Gajewska, M \& Skrzypiec, K 2018, 'Kinetics of nitrogen removal processes in constructed wetlands', E3S Web of Conferences, vol.26, no.1, pp. 1-4.

[12] Gikas, P, Ranieri, E \& Tchobanoglous, G 2013, 'Removal of iron, chromium and lead from wastewater by horizontal subsurface flow constructed wetlands', Journal of Chemical Technology and Biotechnology, vol.88, no.10, pp 1-10.

[13] Grasso, G, Zane, D, Dargone, R 2019 , 'Microbial nanotechnology, Challenges and prospects, for green biocatalytic synthesis of nanoscale materials for senoristic and biomedical applications',nanomaterials, vol.10, no.11, pp. 1-20.

[14] Gremion, F, Chatzinotas, A, von Sigler, KKW \& Harms, H 2004, 'Impacts of heavy metal contamination and phytoremediation on a microbial community during a twelve-month microcosm experiment', FEMS Microbiology Ecology, vol.48, no.2, pp.273-283.

[15] Ibrahim, S, Aliza Kiran, Mehak Rashid, Saba Yamin, Aqsa Zarlish, Shumaila Munir, Rida Tehreem 2015, 'The efficacy of chlorinated water used for irrigation purpose on plant initial growth', Journal of Pharmacognosy and phytochemistry, vol.4, no.4, pp 17-19.

[16] Kadlec, RH \& Wallace, SD 2009, Treatment wetlands, Taylor and Francis group, BocaRaton, Florida, U.S.A.

[17] Karathanasis, AD, Potter, CL \& Coyne, MS 2003, 'Vegetation effects on fecal bacteria, BOD and suspended solid removal in constructed wetlands treating domestic water', Ecological Engineering, vol.20, no.2, pp.157-169.

[18] Klomjek, P 2016, 'Swine wastewater treatment using vertical subsurface flow constructed wetland planted with Napier grass', Sustainable Environmental Research, vol.26, no.5, pp.217223.

[19] Kyambadde, J, Kansiime, F \& Dalhammar, G 2005, 'Nitrogen and phosphorus removal in substrate -free pilot constructed wetlands with horizontal surface flow in Uganda', Water, Air and Soil pollution, vol. 165, no. 1-4, pp. 37-59.

[20] Lima, MX, Carvalho, KQ, Passiq, FH, Borges, AC, Filippe, TC, Azevedo, JCR \& Nagali, A 2018, 'Performance of different substrates in constructed wetlands planted with E. crassipes treating low-strength sewage under subtropical conditions', Science of the Total Environment, vol.630, pp.1365-1373.

[21] Manios, T, Stentiford, I \& Millner, P 2003, 'Removal of total suspended solids from wastewater in constructed horizontal flow subsurface wetlands', Journal of Environmental Science and Health, vol.A38, no.6, pp.1073-1085.

[22] Mello, D, Carvalho, KQ, Passig, FH, Freire, FB, Borges, AC, Lima, MX \& Marcelino, GR 2017, 'Nutrient and organic matter removal from low strength sewage treated with constructed wetlands' Environmental Technology doi:10.1080/09593330.2017.137729. 
[23] Mustapha, HI, van Bruggen, JJA \& Lens, N L 2018, 'Optimization of petroleum refinery wastewater treatment by vertical flow constructed wetlands under tropical conditions: Plant species selection and polishing by a horizontal flow constructed wetland' Water, Air Soil Pollution, vol. 229, no.137, pp.1-17.

[24] Mustapha, HI, van Bruggen, JJA \& Lens, NL 2018 a, ' Fate of heavy metals in vertical subsurface flow constructed wetlands treating secondary treated petroleum refinery wastewater in Kaduna, Nigeria', International Journal of Phytoremediation, vol.20, no.1, pp.44-53.

[25] Norah, M, Shumirai, Z, Zelma, M.L, Upenyu, M 2015, 'Impacts of untreated sewage discharge on water quality of middle Manyame river: A case of Chinhoyi town, Zimbabwe', International Journal of Environmental Monitoring and Analysis, vol.3, no.3, pp.133-138.

[26] Olukanni, DO \& Kokumo, KO 2013, 'Efficiency assessment of a constructed wetland using Eichhornia crassipes for wastewater treatment', American journal of engineering research, vol.2, no.12, pp.450-454.

[27] Pal, S, Joardar, J \& Song, JM 2006, 'Removal of E.coli from water using surface-modified activated carbon filter media and its performance over an extended use', Environmental Science and Technology, vol.40, pp.6091-6097.

[28] Qazi, SA \& Qazi, NS 2008, 'Natural resource conservation and Environment management', Chapter 4, Man and Environment,pp.76-77

[29] Reed, S, Brown, D, Crites, R \& Middlebrooks, E 1995, Natural systems for waste management and treatment, McGraw Hill professional, New York.

[30] Rodriguez, F 2001, Activated carbon and adsorption in Encyclopedia of Materials, Science and Technology.

[31] Sahu, O, 2014, 'Reduction of heavy metals from wastewater by wetland' International Letters of Natural Science, vol.12, pp.35-43. SciPress Ltd., Switzerland.

[32] Sehar, S, Aamir, R, Naz, I, Ali, N \& Ahmed, S 2013. 'Reduction of contaminants (Physical, chemical and microbial) in domestic wastewater through hybrid constructed wetland', ISRN Microbiology, vol.2013, no. 350260, pp.1-9.

[33] Singh, S \& Patidar, SK 2015, 'Performance evaluation of constructed wetland system treating domestic wastewater', Science and Technology, vol. 1, no.4, pp.194-200.

[34] Soda, S, Hamad, T, Yamaok, Y, Ike, M, Nakazato H, Saeki, Y, Kasamatsu, T, Sakurai, Y, 2012,' Constructed wetlands for advanced treatment of wastewater with a complex matrix from a metal-processing plant: Bioconcentration and translocation factors of various metals in Acorus gramineus and Cyperus alternifolius', Ecological Engineering, vol. 39, pp. 63- 70.

[35] Stefanakis, AI \& Tsihrintzis, VA 2012, 'Effects of loading, resting period, temperature, porous media, vegetation and aeration on performance of pilot scale vertical flow constructed wetlands', Chemical Engineering Journal, vol.181, no.182, pp.416-430.

[36] Tiglyene, S, Mandi, L \& Jaouad, AE 2009, 'Removal of chromium from tannery wastewater by vertical infiltration reed beds', Review of Water Sciences, vol.18, no.2, pp.177-198.

[37] Trang, NTD, Konneup, D, Schierup, HH, Chiem, NH, Tuan, LA \& Brix, H 2010, 'Kinetics of pollutant removal from domestic wastewater in a tropical horizontal subsurface flow constructed wetland system: Effects of hydraulic loading rate', Ecological Engineering, vol.36, no.4, pp.527-535.

[38] Tuncsiper, B, Ayaz, S \& Akca, L 2012, 'Coliform bacteria removal from septic wastewater in a pilot scale combined constructed wetland system', Environmental Engineering and Management Journal, vol.11, no.10, pp.1873-1879. 
[39] Usharani, B \& Vasudevan, N, 2017, 'Root exudates of Cyperus alternifolius in partial hydroponic condition under heavy metal stress, Pharmacognosy Research, vol.9, no.3, pp. 294300.

[40] Vacca, G, Wand, H, Nikolausz, M, Kuschk, P \& Kastner, M 2005, 'Effect of plants and filter materials on bacteria removal in pilot- scale constructed wetlands', Journal of Water Research, vol.39, no.7, pp.1361-1373.

[41] Varma, M, Ashok Kumar Gupta, Partha Sarathy Goshal et al., 2020. ' A review on performance of constructed wetland systems in tropical and cold climate, Insights of mechanism, role of influencing factors, and system modification in low temperature conditions', Science of the Total Environment, vol.755,2. 142540.

[42] Van Haandel, A \& Van der Lubbe, J 2012, Handbook of biological wastewater treatment, IWA publishing, London, UK.

[43] Vidya Vijay, M, Sudarsan, JS \& Nithiyanantham, S 2017, 'Sustainability of constructed wetlands in using biochar for treating wastewater', Rasayan Journal of Chemistry, vol.10, no.3, pp.1056-1061.

[44] Vymazal, J 2005, 'Horizontal sub-surface flow and hybrid constructed wetland systems for wastewater treatment', Ecological Engineering, vol.25, pp.478-490.

[45] Wakelin, SA, Colloff, MJ \& Kookana, RS 2008, 'Effect of Wastewater Treatment Plant Effluent on Microbial Function and Community Structure in the Sediment of a Freshwater Stream with Variable Seasonal Flow', Applied and Environmental Microbiology, vol. 74, no. 9, pp. 2659- 2668.

[46] Wang P, Zhang, H, Zuo, J, Zhao, D, Zou, X, Zhu, Z, Jeelani, N, Leng, X \& An, S 2016, 'A hardy plant facilitates nitrogen removal via microbial communities in subsurface flow constructed wetlands in winter', Scientific Reports, vol.6, no.3360, pp.1-10.

[47] WWAP (United Nations World Water Assessment Programme) (2017), The United Nations World Water Development Report, Wastewater: The Untapped Resource, ISBN 978-92-3100201-4, Paris.

[48] Yadav, SB, Jadhav, AS, Chonde, SG \& Raut, PD 2011, 'Performance of surface flow constructed wetland system by using Eichhornia crassipes for wastewater treatment in an institutional complex', Universal Journal of Environmental Research and Technology, vol.1, no.4, pp.435-441.

[49] Yang, Z, Wang, Q, Zhang, J, Xie, H \& Feng, S 2016, 'Effect of plant harvesting on the performance of constructed wetlands during summer', Water, vol.8, no.24, pp.1-10.

[50] Zhao, Y, Liu, B, Zhang, W, Kong, W, Hu, C \& An, S 2009, 'Comparison of the treatment performances of high- strength wastewater in vertical subsurface flow constructed wetlands planted with Acorus calamus and Lythrum salicaria', Journal of Health Science, vol.55, no.5, pp.757-766.

[51] Zurita, F \& Carreon -Alvarez 2015, 'Performance of three pilot-scale hybrid constructed wetlands for total coliforms and Escheria coli removal from primary effluent- a 2 year study in a subtropical climate', Journal of Water and Health, vol.13, no.2, pp. 446-458.

[52] Zurita, F \& White, JR, 2014, 'Comparative study of three two-stage hybrid ecological wastewater treatment systems for producing high nutrient, reclaimed water for irrigation reuse in developing counties', Water, vol. 6, pp. 213-228. 